A product of the California Groundwater Ambient Monitoring and Assessment Program

Prepared in cooperation with California State Water Resources Control Board

\title{
Identification of Bacteria in Groundwater Used for Domestic Supply in the Southeast San Joaquin Valley, California, 2014
}

Scientific Investigations Report 2021-5030 
Cover Photograph: Samples with detections of total coliforms. The colonies show up as fluorescent spots on the MI media plates. Photograph taken by Carmen Burton. 


\section{Identification of Bacteria in Groundwater Used for Domestic Supply in the Southeast San Joaquin Valley, California, 2014}

By Carmen A. Burton and Christine J. Lawrence

A product of the California Groundwater Ambient Monitoring and Assessment

Program

Prepared in cooperation with California State Water Resources Control Board

Scientific Investigations Report 2021-5030 


\section{U.S. Geological Survey, Reston, Virginia: 2021}

For more information on the USGS - the Federal source for science about the Earth, its natural and living resources, natural hazards, and the environment—visit https://www.usgs.gov or call 1-888-ASK-USGS.

For an overview of USGS information products, including maps, imagery, and publications, visit https://store.usgs.gov/.

Any use of trade, firm, or product names is for descriptive purposes only and does not imply endorsement by the U.S. Government.

Although this information product, for the most part, is in the public domain, it also may contain copyrighted materials as noted in the text. Permission to reproduce copyrighted items must be secured from the copyright owner.

Suggested citation:

Burton, C.A., and Lawrence, C.J., 2021, Identification of bacteria in groundwater used for domestic supply in the southeast San Joaquin Valley, California, 2014: U.S. Geological Survey Scientific Investigations Report 2021-5030, 20 p., https://doi.org/10.3133/sir20215030.

Associated data for this publication:

Soldavini, A.L., Burton, C.A., and Lawrence, C.J., 2021, Detections of fecal indicator bacteria and DNA sequencing of selected bacterial growths in samples from the Madera/Chowchilla-Kings domestic aquifer study unit, 2014: Results from the California GAMA priority basin project: U.S. Geological Survey data release, https://doi.org/10.5066/P9X7JH11.

ISSN 2328-0328 (online) 


\section{Acknowledgments}

This study was supported by the California State Water Resources Control Board and U.S. Geological Survey (USGS) Cooperative Matching Funds. We thank the well owners who graciously allowed the USGS to collect samples from their domestic well and the various USGS field crews for the collection of samples. 



\section{Contents}

Acknowledgments ……...................................................................................................................

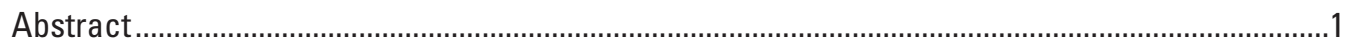

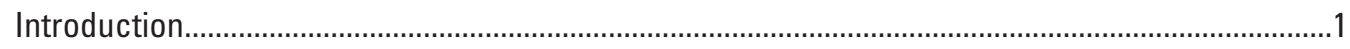

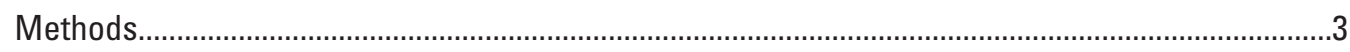

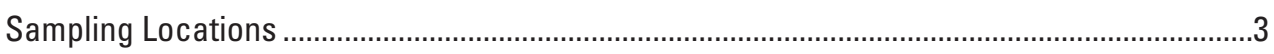

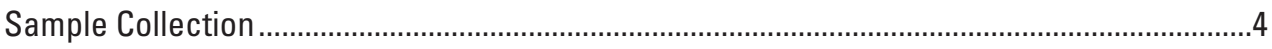

Analysis of Total Coliforms, Escherichia coli, and Enterococci...............................................

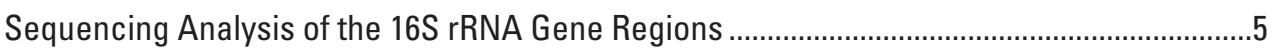

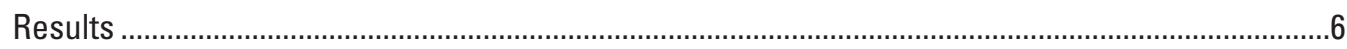

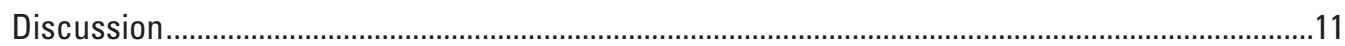

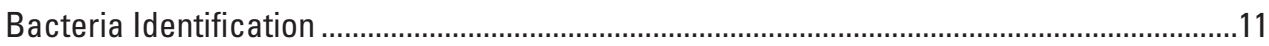

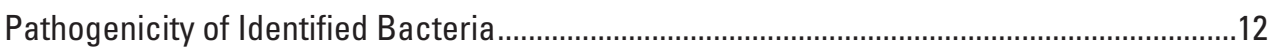

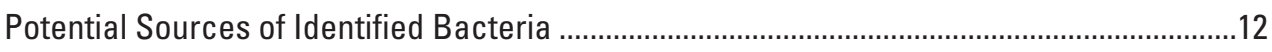

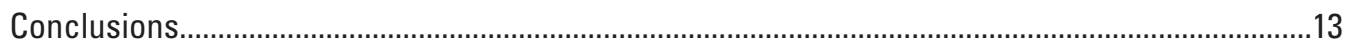

References Cited................................................................................................................

\section{Figures}

1. Map showing location of the Chowchilla, Madera, and Kings groundwater subbasins of the San Joaquin Valley, California, well sites, and type of microbial detections for samples collected from January to April 2014

2. Photograph showing results of electrophoresis on a Lonza FlashGel cassette showing bands at 700 base pairs indicating successful Polymerase chain reaction amplification reactions

\section{Tables}

1. List of domestic sites sampled for fecal indicator bacteria and number of colony-forming units per 250 milliliters of sample from cultures on $\mathrm{MI}$ and $\mathrm{mEI}$ media in the southeastern San Joaquin Valley from January to April 2014

2. Genera of bacteria that were identified as target and non-target colonies on MI media where DNA was successfully sequenced from 14 groundwater samples collected from 13 domestic wells in the southeastern San Joaquin Valley from January to April 2014

3. Pathogenicity, microbial source, and selected references for genera identified in samples collected from wells in the southeastern San Joaquin Valley from January to April 2014 


\section{Conversion Factors}

International System of Units to U.S. customary units

\begin{tabular}{|c|c|c|}
\hline Multiply & By & To obtain \\
\hline \multicolumn{3}{|c|}{ Length } \\
\hline nanometer (nm) & 0.00000003947 & inch (in.) \\
\hline micrometer $(\mu \mathrm{m})$ & 0.00003937 & inch (in.) \\
\hline meter $(\mathrm{m})$ & 3.281 & foot $(\mathrm{ft})$ \\
\hline kilometer (km) & 0.6214 & mile (mi) \\
\hline \multicolumn{3}{|c|}{ Area } \\
\hline square meter $\left(\mathrm{m}^{2}\right)$ & 10.76 & square foot $\left(\mathrm{ft}^{2}\right)$ \\
\hline square kilometer $\left(\mathrm{km}^{2}\right)$ & 0.3861 & square mile $\left(\mathrm{mi}^{2}\right)$ \\
\hline \multicolumn{3}{|c|}{ Volume } \\
\hline liter (L) & 1.057 & quart (qt) \\
\hline cubic meter $\left(\mathrm{m}^{3}\right)$ & 264.2 & gallon (gal) \\
\hline \multicolumn{3}{|c|}{ Flow rate } \\
\hline cubic meter per day $\left(\mathrm{m}^{3} / \mathrm{d}\right)$ & 35.31 & cubic foot per day $\left(\mathrm{ft}^{3} / \mathrm{d}\right)$ \\
\hline \multicolumn{3}{|c|}{ Mass } \\
\hline gram $(\mathrm{g})$ & 0.03527 & ounce, avoirdupois (oz) \\
\hline kilogram (kg) & 2.205 & pound avoirdupois (lb) \\
\hline \multicolumn{3}{|c|}{ Pressure } \\
\hline kilopascal $(\mathrm{kPa})$ & 0.1450 & pound per square inch $\left(\mathrm{lb} / \mathrm{ft}^{2}\right)$ \\
\hline
\end{tabular}

Temperature in degrees Celsius $\left({ }^{\circ} \mathrm{C}\right)$ may be converted to degrees Fahrenheit $\left({ }^{\circ} \mathrm{F}\right)$ as follows:

$$
{ }^{\circ} \mathrm{F}=\left(1.8 \times{ }^{\circ} \mathrm{C}\right)+32 .
$$

\section{Datum}

Vertical coordinate information is referenced to the North American Vertical Datum of 1988 (NAVD 88).

Horizontal coordinate information is referenced to the North American Datum of 1983 (NAD 83). 


\section{Abbreviations}

$\begin{array}{ll}\text { BLAST } & \text { basic local alignment search tool } \\ \text { CDC } & \text { Centers for Disease Control and Prevention } \\ \text { CFU } & \text { colony forming unit } \\ \text { DNA } & \text { deoxyribonucleic acid } \\ \text { EPA } & \text { U.S. Environmental Protection Agency } \\ \text { FIB } & \text { fecal indicator bacteria } \\ \text { GAMA-PBP } & \text { Groundwater Ambient Monitoring and Assessment Program Priority } \\ \text { MCL } & \text { Basin Project } \\ \text { PAH } & \text { maximum contaminant level } \\ \text { PCR } & \text { polycyclic aromatic hydrocarbon } \\ \text { rDNA } & \text { polymerase chain reaction } \\ \text { rRNA } & \text { ribosomal deoxyribonucleic acid } \\ \text { Taq polymerase } & \text { ribosomal ribonucleic acid } \\ \text { TC } & \text { Thermus aquaticus polymerase } \\ \text { USGS } & \text { total coliforms } \\ & \text { U.S. Geological Survey }\end{array}$





\title{
Identification of Bacteria in Groundwater Used for Domestic Supply in the Southeast San Joaquin Valley, California, 2014
}

\author{
By Carmen A. Burton ${ }^{1}$ and Christine J. Lawrence ${ }^{2}$
}

\begin{abstract}
Groundwater is an important source of drinking water in California. Water-borne diseases caused by microbial contamination are a growing concern. The MI test, a membrane filtration method for the chromogenic/fluorogenic detection of total coliforms and Escherichia coli, was used for samples collected January to April 2014 from 42 domestic wells in the southeastern San Joaquin Valley. The wells were sampled as part of the Groundwater Ambient Monitoring and Assessment Program Priority Basin Project (GAMA-PBP), a cooperative study between the U.S. Geological Survey and the California State Water Resources Control Board. Polymerase chain reaction analysis and sequencing of deoxyribonucleic acid (DNA) were used for 34 target and nontarget colonies that grew on the MI media from samples collected from 13 of the domestic wells to identify what genera of bacteria could exist in groundwater used by domestic wells. Gene sequences obtained using the Sanger method were entered into the basic local alignment search tool (BLAST) database, and 17 genera of bacteria were identified. Of these, 13 genera contain species that are human pathogens or opportunistic human pathogens. All the genera that include human pathogens are naturally present in soil, plants, or water; one of the pathogens also can be found in fecal matter. Six of the human pathogens were from non-target colony growth on the MI media. Target and non-target microbial growth on MI media are indicators of the possible presence of pathogenic bacteria even if the bacteria naturally are from soil rather than from a fecal source.
\end{abstract}

${ }^{1}$ U.S. Geological Survey

${ }^{2}$ Formerly with the U.S. Geological Survey

\section{Introduction}

Diseases can be spread by waterborne microbial pathogens in groundwater. Most waterborne microbial pathogens are derived from human or animal waste; however, evidence exists that many microorganisms can survive in viable but nonculturable forms in non-fecal conditions (Levin and others, 2002). For the years 2013-14, the Centers for Disease Control and Prevention (CDC) listed 42 reported outbreaks associated with drinking water (Benedict and others, 2017). Of the 42 outbreaks, 9 were caused by pathogens in groundwater. To test for each pathogen is difficult, prohibitively costly, and risks pathogenic exposure to the person doing the test. Fecal indicator bacteria (FIB), such as total coliforms (TCs) and enterococci, are commonly used to indicate the possible presence of waterborne disease-causing organisms of fecal origin. Fecal indicator bacteria were chosen as indicators of potential microbial contamination in the U.S. Environmental Protection Agency's (EPA) “total coliform rule and ground water rule" because they generally are not pathogenic, are easy to culture, and can be fecal in origin (U.S. Environmental Protection Agency, 2008, 2020b).

Coliforms inhabit the intestines of warm-blooded animals and are found in feces. Coliforms also are present in soil, on vegetation, and in water (Foppen and Schijven, 2006; Brennan and others, 2010; Krentz, 2012). Studies show that Escherichia coli (E. coli), one species of coliform always found in feces, and enterococci, another group of bacteria that are mostly of fecal origin, could be better indicators of fecal contamination than TCs (U.S. Environmental Protection Agency, 1986). 
About 60 percent of the water used for public and domestic drinking-water supply in California is groundwater (Dieter and others, 2018). Public-supply wells are routinely tested for TCs and E. coli as part of regulatory compliance monitoring, and corrective actions are taken if the maximum contaminant levels (MCLs) are exceeded (U.S. Environmental Protection Agency, 2008; California State Water Resources Control Board, 2019). In contrast, the State of California and the EPA do not regulate water quality in privately owned domestic wells (California State Water Resources Control Board, 2015; U.S. Environmental Protection Agency, 2020a). In a study by the U.S. Geological Survey (USGS) of domestic wells from 1991 to 2004, 34 percent of wells tested positive for TCs and 8 percent tested positive for E. coli (DeSimone and others, 2009). Testing of domestic wells in six California counties by the California State Water Resources Control Board found 14 to 33 percent of the wells tested positive for TCs, with the highest frequency in Tulare County in the southeast San Joaquin Valley (California State Water Resources Control Board, 2018). No information is available concerning the genera of bacteria causing these TC detections in the California domestic wells, however. Knowledge about the genera gives information about the possible origin of the bacteria, which informs what type of action might be needed to protect the well or the consumers of the water from the well from microbial contamination. In addition, knowledge of the genera could be useful for assessing the selectivity and specificity of commonly used TC tests for indicating the presence of potentially pathogenic bacteria.

The EPA has approved several analytical methods for monitoring FIBs including traditional membrane filtration methods and defined substrate technology (Covert and others, 1989; Brenner and others, 1996; U.S. Environmental
Protection Agency, 2002, 2006, 2008; Buckalew and others, 2006; Oldstadt and others, 2007; Zhang and others, 2015). Polymerase chain reaction (PCR) analysis is widely used to identify bacteria. In particular, the $16 \mathrm{~S}$ ribosomal ribonucleic acid (rRNA) gene is a well-studied universal gene in bacteria and is a standard method for the identification of species (Barry and others, 1991; Jensen and others, 1993; Gürtler and Stanisich, 1996; Clermont and others, 2000; Ryu and others, 2013). The membrane filtration methods result in bacterial colonies that can be used for PCR analysis for identification of bacteria in the water samples that the defined substrate methods do not. Two common membrane filtration methods use MI medium (Brenner and others, 1993; U.S. Environmental Protection Agency, 2002) and mEI medium (U.S. Environmental Protection Agency, 2006).

The USGS has an ongoing statewide assessment of water quality in groundwater resources used for drinking-water supplies for the California State Water Resources Control Board's Groundwater Ambient Monitoring and Assessment Program Priority Basin Project (GAMA-PBP). The FIB samples were collected as part of a GAMA-PBP study of domestic wells in the southeastern part of the San Joaquin Valley from January to April 2014 (fig. 1). As the FIB tests used in this study are not genera- or species-specific, the objective of this study was to identify the genera of bacteria cultured by these FIB methods from samples collected at domestic wells. The purposes of this report are to (1) identify some of the genera of bacteria that can be present in domestic wells in the San Joaquin Valley, (2) examine potential pathogenicity of bacteria cultured on MI media, and (3) present results of a literature review describing the general sources of bacteria identified by FIB methods. 


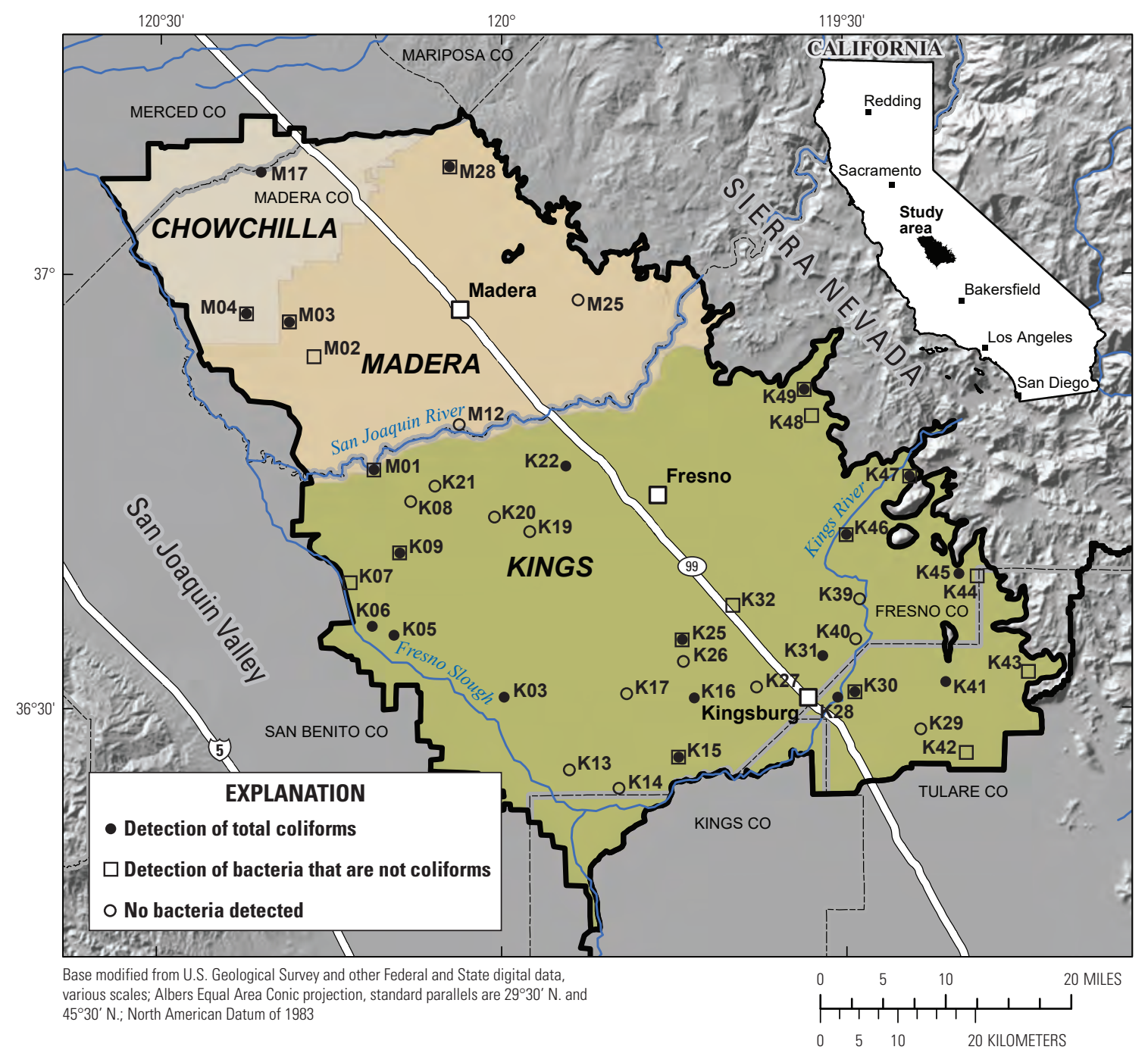

Figure 1. Location of the Chowchilla, Madera, and Kings groundwater subbasins of the San Joaquin Valley, California, well sites, and type of microbial detections for samples collected from January to April 2014.

\section{Methods}

\section{Sampling Locations}

This study was part of the GAMA-PBP assessment of domestic wells in the Chowchilla, Madera, and Kings groundwater subbasins of the San Joaquin Valley (fig. 1; Shelton and Fram, 2017). This region was selected for study because many of the households rely on domestic wells as their sole source of drinking-water supply (Johnson and Belitz, 2015). The aquifer system used by domestic wells in this region of the San Joaquin Valley primarily consists of Quaternary unconsolidated alluvial fan and fluvial gravel, sand, silt, and clay sediments interbedded with lesser amounts of lacustrine deposits (Davis and others, 1959; Faunt, 2009;
California Department of Water Resources, 2003, 2008a, b). The sediments were derived from the weathering of the mostly granitic rocks of the Sierra Nevada. More than 60 percent of the wells sampled were in areas where 40 percent or more of the aquifer sediments consisted of coarse-grained sediments, and recharge rates, as measured by downward vertical flux, typically ranged from 1,600 to more than 7,600 cubic meters per day (Faunt, 2009). Groundwater generally flows westerly from the Sierra Nevada. Samples from 42 wells of the 77 wells sampled for the GAMA-PBP assessment were analyzed to identify the genera of bacteria that can exist in the well water. Well depths for the 42 wells ranged from 30 to 104 meters (median 55 meters), and depth to water was 9 to 67 meters (median 28 meters; Shelton and Fram, 2017). Samples were identified by a shortened form of the GAMA-PBP identification number given in Shelton and Fram (2017). 


\section{Sample Collection}

Groundwater samples were collected using protocols described in USGS National Field Manual (U.S. Geological Survey, variously dated) from January to April 2014 (Shelton and Fram, 2017). Domestic wells were purged, removing one or more well volumes of standing water depending on estimated water use of the domestic wells in the previous 24 hours, until at least three casing volumes of water were removed per standard USGS procedures. Purging continued until field measurements of $\mathrm{pH}$, temperature, dissolved oxygen, and specific conductance stabilized (U.S. Geological Survey, variously dated). Prior to the collection of microbial samples, the sample point was disinfected by spraying it inside and out with ethanol, allowing it to dry, and then rinsing it with sterile deionized water. Water samples were collected in sterile polypropylene bottles from points prior to where the water passes through any holding tanks or chemical treatment systems. Samples were shipped overnight on ice to the USGS California Water Science Center in San Diego, Calif., for analysis. Duplicate samples were collected at six sites (14 percent of the sites).

\section{Analysis of Total Coliforms, Escherichia coli, and Enterococci}

The presence of TCs and E. coli was determined by USEPA Method 1604, a membrane filtration method on MI medium (U.S. Environmental Protection Agency, 2002). The presence of enterococci was determined by USEPA Method 1600, a membrane filtration method on mEI medium (U.S. Environmental Protection Agency, 2006). The MI medium includes a fluorogen that reacts with the enzyme $\beta$-galactosidase found in TCs and a chromogen that reacts with the enzyme $\beta$-glucuronidase found in $E$. coli. A cephalosporin antibiotic, cefsulodin, is added to the MI medium to inhibit non-target growth. The mEI medium includes the chromogen indoxyl $\beta$-D-glucoside, which interacts with $\beta$-glucosidase-positive enterococci. Samples were analyzed within 24-30 hours of collection. All equipment was sterilized by autoclave at 121 degrees Celsius $\left({ }^{\circ} \mathrm{C}\right)$ and 103 kilopascals for at least 15 minutes. Sterile phosphate buffer was obtained from Hardy Diagnostics (Santa Maria, Calif.). The MI and $\mathrm{mEI}$ media were obtained from the USGS Ohio Microbiology Lab, Columbus, Ohio. Positive and negative control cultures were obtained from IDEXX Laboratories (Westbrook, Maine).

Microbial samples were processed using protocols described in the USGS National Field Manual (Myers and others, 2014). Aliquots of 250 milliliters (mL) of sample were vacuum filtered onto 0.45 micrometer $(\mu \mathrm{m})$ gridded membranes, and the membrane was placed on plated media. An aliquot of $250 \mathrm{~mL}$, instead of the usual $100 \mathrm{~mL}$, was filtered to increase the chances of obtaining bacterial growth. Two aliquots of sample were filtered for each type of media. Samples on MI media were incubated at $35{ }^{\circ} \mathrm{C}$ for 22-26 hours, and samples on mEI media were incubated at $41^{\circ} \mathrm{C}$ for $22-26$ hours. After incubation, the bacteria colonies on the plates were counted. Any plates showing growth were stored at $4{ }^{\circ} \mathrm{C}$ and retained for sequencing analysis. Plates were stored for up to 4 days before further analysis.

Quality control consisted of positive and negative controls cultured on each lot of medium used; field, filter, and procedure blanks; and field duplicates. Positive control bacteria used for MI medium were E. coli and Klebsiella pneumoniae, and the negative control was Pseudomonas aeruginosa. The positive control for $\mathrm{mEI}$ medium was Enterococcus faecalis, and the negative controls were $E$. coli and Streptococcus bovis. A total of eight sets of positive and negative control samples were analyzed, one at the start of each lot of media used and one at the end of each lot of media used during the study. In all cases, the positive controls showed colony growth, and the negative controls did not, indicating each lot of media for the MI and mEI methods performed as required.

Field blanks were collected from six sites using sterile phosphate buffer and processed using the same procedures as for environmental samples. Field blanks were used to assess contamination introduced during the collection process. Filter blanks were processed before each sample was plated. Procedure blanks were processed between sample aliquots plated on MI medium and on mEI medium. For filter and procedure blanks, $50 \mathrm{~mL}$ of sterile phosphate buffer was filtered through a $0.45-\mu \mathrm{m}$ gridded membrane filter. The membrane filter was plated on MI or $\mathrm{mEI}$ media. The filter blanks were used to assess contamination introduced in the laboratory during sample preparation activities. The procedure blank was used to test for completeness and sterility of the filtering process from one aliquot to the next. All field blanks, filter blanks, and procedure blanks showed no colony growth, which indicated no contamination by FIBs was introduced during collection and processing of the samples. Duplicates were collected from six sites. For one duplicate pair, TC was detected in the environmental sample but not the replicate; there were no detections of $E$. coli or enterococci for either sample of all six duplicate pairs; and three duplicate pairs yielded growth of non-target organisms (colonies that do not fluoresce blue) on MI media in the duplicate but not the environmental sample.

The definition of a coliform varies depending on the country or organization in charge of microbiological regulations and the method used. For MI media, the definition of a coliform is any bacteria that fluoresces blue-green or blue-white under longwave ultraviolet light (366 nanometers). A phenotypic definition is more specific and defines coliforms as rod-shaped, Gram-negative, non-spore forming bacteria that ferment lactose with production of acid and gas when incubated at $35-37^{\circ} \mathrm{C}$ and reacts positively with ß-D-galactosidase. For simplicity, with a few exceptions, this report uses the MI definition of a coliform. 


\section{Sequencing Analysis of the 16S rRNA Gene Regions}

The universal 16S rRNA gene is a component of a prokaryotic ribosome, a complex of $16 \mathrm{~S}$ rRNA and ribonucleoproteins. The parts of the rRNA that carry out essential functions are highly conserved across nearly all bacterial species (Jensen and others, 1993; Gürtler and Stanisich, 1996). The structural parts of the rRNA are largely variant, however, and are referred to as hypervariable regions. The sequence of ribosomal deoxyribonucleic acid (rDNA) in the hypervariable regions of bacteria is used for phylogenetic analysis and genera and species identification (Barry and others, 1991; Jensen and others, 1993; Gürtler and Stanisich, 1996).

Sequencing of a part of the hypervariable region of rDNA followed the procedures modified from Barry and others (1991). In general, the universal primers are used to flank a sequence of the 16S hypervariable region of rDNA, then PCR is used to amplify this region, and the region is sequenced and the genera and species containing that sequence are identified. Three sets of primers and two annealing temperatures were tested on cultures of Klebsiella pneumoniae, Enterococcus faecalis, and E. coli to determine which set of universal primers and temperature to use.

The forward universal primer $8 \mathrm{~F}$

(5'-AGAGTTTGATCCTGGCTCAG-3') and the reverse universal primer 787R (5'-CGACTACCAGGGTATCTAAT-3') were selected to amplify a region of $16 \mathrm{~S}$ rDNA that codes for a component of the $30 \mathrm{~S}$ small subunit of prokaryotic ribosomes and includes the hypervariable regions that can provide a sequence to identify a genus or species of bacteria. A sample from a target colony or a non-target colony that grew on the MI media was taken by dipping a sterile pipette tip into the colony, and the cells were transferred into a PCR tube with 25 microliters $(\mu \mathrm{L})$ of a PCR solution mix. The mix contained $5 \mu \mathrm{L}$ of $5 \mathrm{X}$ Q-solution, $2.5 \mu \mathrm{L}$ of tris-borate-EDTA $10 \mathrm{X}$ buffer, $1.25 \mu \mathrm{L}$ of a 25 millimolar magnesium chloride solution, $1.25 \mu \mathrm{L}$ of deoxynucleotide triphosphate (dNTP) solution, $0.5 \mu \mathrm{L}$ of 10 micromolar solutions of each of the two primers, and $0.125 \mu \mathrm{L}$ of Taq polymerase in deionized water. Amplifications used a Bio-Rad T100 Thermocycler and included a 3-minute denaturing step at $95^{\circ} \mathrm{C}$, followed by 30 cycles of 30 seconds at $94{ }^{\circ} \mathrm{C}$, an annealing step at $55.2^{\circ} \mathrm{C}$ for 45 seconds, followed by 1 minute at $72{ }^{\circ} \mathrm{C}$, and a final extension of 10 minutes at $72{ }^{\circ} \mathrm{C}$. Primers were ordered from Operon Lab, Taq polymerase from Fisher Scientific, and dNTP mix from Life Technologies. Phase-streaking of the selected colonies was not done to ensure that the colonies of interest were from a single bacteria cell before PCR analysis. It is therefore possible that cells from more than one species were added to the PCR mix.

The results of the PCR were analyzed with gel electrophoresis using Lonza FlashGel. If the PCR reaction was successful, a distinct band or smudge is seen around 700 base pairs (fig. 2). Samples for which the PCR products show a distinct band or smudge on the gel were purified with UltraClean PCR Clean-Up Kit from Mo Bio Laboratories. The purified PCR product was sequenced by the Sanger sequencing method (Sanger and Coulson, 1975; Sanger and others, 1977) by GeneWiz Laboratory, San Diego, Calif. The sequence was entered into the basic local alignment search tool (BLAST) database for species identification (National Center for Biotechnology Information, 2019). Along with the genus and species identification, the percentage of query coverage and identity were obtained. Query coverage is the percentage of the sequence length of the colony DNA that is aligned with DNA segments of the BLAST database sequence. Identity is the extent to which the two sequences have the same nucleotide at the same position in an alignment (Fassler and Cooper, 2011). The greater the query coverage or identity, the more likely that the correct genus or species is identified. Quality control consisted of testing the primers with cultures of $K$. pneumoniae, E. coli, P. aeruginosa, and E. faecalis. All the control bacteria were correctly identified. Information obtained from the literature was used to determine the most likely genus or species when the BLAST database produced multiple options for a given sequence. The DNA-sequence data are published in a companion USGS ScienceBase data release (Soldavini and others, 2021). 


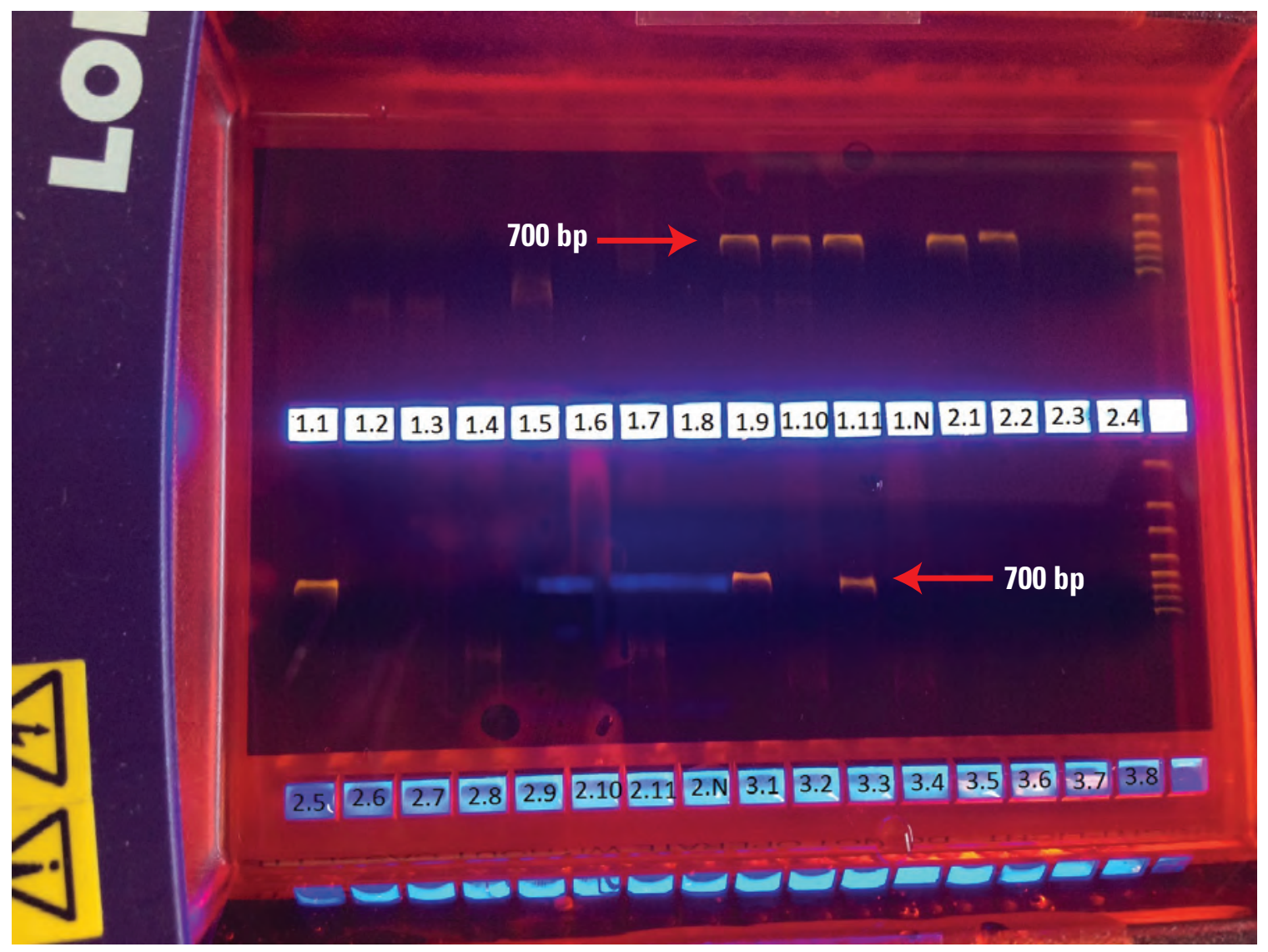

Figure 2. Results of electrophoresis on a Lonza FlashGel cassette showing bands at 700 base pairs (bp) indicating successful polymerase chain reaction (PCR) amplification reactions.

\section{Results}

Samples from 27 of the 42 domestic groundwater wells had at least one colony forming unit (CFU) of either TCs, non-target growth, or both (table 1). E. coli and enterococci were not observed in any of the samples. Samples from 20 of the 42 wells had at least one CFU of TCs, and samples from 18 of the 42 wells had at least one CFU of non-target organisms. For samples with detections of TC, half also had non-target growth. For those samples without detections of TC, nearly one-third had non-target growth. The range of colonies counted per sample with growth (including duplicates) on the MI media was 1 to 144 (median =4).

PCR was run on 106 of the 579 colonies that grew on the MI media during this study: 57 target colonies and 49 non-target colonies. Amplification of the section of DNA flanked by the primers was successful for 59 colonies based on the FlashGel electrophoresis and sent to GeneWiz for sequencing of the bases. Sequencing was successful for 34 of the 59 colonies (19 from TC colonies and 15 from non-target colonies). The gene sequences were entered into the BLAST database for identification, and the results are given in table 2 . The number of bases in a sequence ranged from 450 to 901 bases. Seventeen different genera were identified. The percentages of query coverage and identity that indicate the certainty of genus or species identification also are shown in table 2 . The query coverage of the gene sequences ranged from 79 to 100 percent (median 100 percent, mean 98.3 percent), and the certainty of identity ranged from 87 to 100 percent (median 99 percent, mean 97.8 percent; table 2). Even when the percentages of query coverage or certainty of identity were high (95 percent or higher), five colonies had more than one potential genus identified (for example, K30 and $\mathrm{K} 49$ each had two potential genera). Information about habitat and source obtained from the literature (table 3) was used to determine which genus was most likely to be correct when the BLAST database produced multiple genera for a given sequence.

The MI test defines TCs as bacteria that produce blue-fluorescent colonies upon exposure to longwave ultraviolet light after culturing on MI medium. Four genera of bacteria, Achromobacter, Chryseobacterium, Cupriavidus, and Pseudomonas, were identified in both target and non-target colonies from samples collected from domestic wells, but not in the same well. The bacteria are not coliform bacteria and should not have been identified from target colonies. 
Table 1. List of domestic sites sampled for fecal indicator bacteria and number of colony-forming units (CFUs) per 250 milliliters of sample from cultures on MI and mEl media, southeastern San Joaquin Valley, January to April 2014.

[Well identification number is a shortened form of the GAMA-PBP identification number given in Shelton and Fram (2017). Escherichia coli and enterococci were not detected in any of the samples. Abbreviations: GAMA-PBP; Groundwater Ambient Monitoring and Assessment Priority Basin Project; USGS, U.S. Geological Survey; mm/dd/yyyy, month/day/year; CFU, colony forming unit]

\begin{tabular}{|c|c|c|c|c|c|c|}
\hline $\begin{array}{c}\text { Well } \\
\text { identification } \\
\text { number }\end{array}$ & $\begin{array}{c}\text { GAMA-PBP } \\
\text { identification } \\
\text { number }\end{array}$ & $\begin{array}{c}\text { USGS site } \\
\text { identification } \\
\text { number }\end{array}$ & $\begin{array}{c}\text { California state well } \\
\text { number }\end{array}$ & $\begin{array}{l}\text { Date sampled } \\
\text { (mm/dd/yyyy) }\end{array}$ & $\begin{array}{c}\text { Number } \\
\text { of total } \\
\text { coliforms } \\
\text { (CFUs) }\end{array}$ & $\begin{array}{c}\text { Number of } \\
\text { non-target } \\
\text { colonies } \\
\text { (CFUs) }\end{array}$ \\
\hline K03 & S3-MACK-K03 & 363000119590001 & 16S/18E-27B1M & $01 / 28 / 2014$ & 1 & 0 \\
\hline K05 & S3-MACK-K05 & 363500120090001 & 15S/17E-31G1M & $01 / 30 / 2014$ & 5 & 0 \\
\hline K06 & S3-MACK-K06 & 363500120110001 & $15 \mathrm{~S} / 16 \mathrm{E}-26 \mathrm{H} 2 \mathrm{M}$ & $01 / 29 / 2014$ & 2 & 0 \\
\hline K07 & S3-MACK-K07 & 363800120130001 & 15S/16E-03N1M & $04 / 08 / 2014$ & 0 & 1 \\
\hline K07 & S3-MACK-K07 & 363800120130001 & $15 \mathrm{~S} / 16 \mathrm{E}-03 \mathrm{~N} 1 \mathrm{M}$ & Duplicate & 0 & 0 \\
\hline K08 & S3-MACK-K08 & 364400120070001 & 14S/17E-05J1M & $01 / 28 / 2014$ & 0 & 0 \\
\hline K09 & S3-MACK-K09 & 364000120080001 & 14S/17E-29M1M & $02 / 23 / 2014$ & 1 & 136 \\
\hline K13 & S3-MACK-K13 & 362500119540001 & 017S019E22N002M & $01 / 27 / 2014$ & 0 & 0 \\
\hline K14 & S3-MACK-K14 & 362400119490001 & 017S020E32E001M & $01 / 27 / 2014$ & 0 & 0 \\
\hline $\mathrm{K} 15$ & S3-MACK-K15 & 362600119440001 & 017S021E18N001M & $02 / 03 / 2014$ & 19 & 1 \\
\hline K16 & S3-MACK-K16 & 363000119430001 & 016S021E30H001M & $02 / 03 / 2014$ & 3 & 0 \\
\hline K17 & S3-MACK-K17 & 363100119490001 & 016S020E20Q002M & $02 / 04 / 2014$ & 0 & 0 \\
\hline K19 & S3-MACK-K19 & 364200119570001 & 014S018E24B001M & $02 / 05 / 2014$ & 0 & 0 \\
\hline $\mathrm{K} 20$ & S3-MACK-K20 & 364300120000001 & 014S018E09Q001M & $03 / 06 / 2014$ & 0 & 0 \\
\hline $\mathrm{K} 21$ & S3-MACK-K21 & 364500120050001 & 013S017E34H001M & $02 / 05 / 2014$ & 0 & 0 \\
\hline K21 & S3-MACK-K21 & 364500120050001 & 013S017E34H001M & Duplicate & 0 & 0 \\
\hline $\mathrm{K} 22$ & S3-MACK-K22 & 364600119540001 & 013S019E21Q001M & $01 / 29 / 2014$ & 2 & 0 \\
\hline K25 & S3-MACK-K25 & 363400119440001 & 015S020E36J001M & $02 / 26 / 2014$ & 8 & 4 \\
\hline $\mathrm{K} 26$ & S3-MACK-K26 & 363325119440901 & 016S021E07E001M & $02 / 04 / 2014$ & 0 & 0 \\
\hline K27 & S3-MACK-K27 & 363100119370001 & 016S021E24H001M & $03 / 04 / 2014$ & 0 & 0 \\
\hline $\mathrm{K} 28$ & S3-MACK-K28 & 363000119300001 & 016S023E30G001M & $03 / 18 / 2014$ & 1 & 0 \\
\hline K29 & S3-MACK-K29 & 362800119230001 & 017S024E05K001M & $03 / 17 / 2014$ & 0 & 0 \\
\hline K29 & S3-MACK-K29 & 362800119230001 & 017S024E05K001M & Duplicate & 0 & 0 \\
\hline $\mathrm{K} 30$ & S3-MACK-K30 & 363100119290001 & 016S023E20R001M & $02 / 06 / 2014$ & 9 & 8 \\
\hline K31 & S3-MACK-K31 & 363300119310001 & 016S022E01P001M & $02 / 27 / 2014$ & 3 & 0 \\
\hline K32 & S3-MACK-K32 & 363712119394801 & 015S021E14N002M & $04 / 07 / 2014$ & 0 & 0 \\
\hline K32 & S3-MACK-K32 & 363712119394801 & 015S021E14N002M & Duplicate & 0 & 2 \\
\hline K39 & S3-MACK-K39 & 363700119280001 & 015S023E16E001M & $03 / 03 / 2014$ & 0 & 0 \\
\hline K39 & S3-MACK-K39 & 363700119280001 & 015S023E16E001M & Duplicate & 0 & 0 \\
\hline K40 & S3-MACK-K40 & 363400119290001 & 015S023E32J001M & $02 / 25 / 2014$ & 0 & 0 \\
\hline K41 & S3-MACK-K41 & 363100119210001 & 016S024E22C001M & $03 / 04 / 2014$ & 1 & 0 \\
\hline K42 & S3-MACK-K42 & 362600119190001 & 017S024E13L001M & 03/17/2014 & 0 & 8 \\
\hline K43 & S3-MACK-K43 & 363200119140001 & 016S025E15A001M & $03 / 05 / 2014$ & 0 & 5 \\
\hline K44 & S3-MACK-K44 & 363900119180001 & 015S024E01J001M & $03 / 05 / 2014$ & 0 & 1 \\
\hline K45 & S3-MACK-K45 & 363900119200001 & 015S024E02F001M & $02 / 25 / 2014$ & 46 & 0 \\
\hline $\mathrm{K} 46$ & S3-MACK-K46 & 364200119290001 & 014S023E20F003M & $02 / 24 / 2014$ & 4 & 0 \\
\hline K46 & S3-MACK-K46 & 364200119290001 & 014S023E20F003M & Duplicate & 0 & 3 \\
\hline
\end{tabular}


Table 1. List of domestic sites sampled for fecal indicator bacteria and number of colony-forming units (CFUs) per 250 milliliters of sample from cultures on MI and mEl media, southeastern San Joaquin Valley, January to April 2014. - Continued

[Well identification number is a shortened form of the GAMA-PBP identification number given in Shelton and Fram (2017). Escherichia coli and enterococci were not detected in any of the samples. Abbreviations: GAMA-PBP; Groundwater Ambient Monitoring and Assessment Priority Basin Project; USGS, U.S. Geological Survey; mm/dd/yyyy, month/day/year; CFU, colony forming unit]

\begin{tabular}{ccccccc}
\hline $\begin{array}{c}\text { Well } \\
\text { identification } \\
\text { number }\end{array}$ & $\begin{array}{c}\text { GAMA-PBP } \\
\text { identification } \\
\text { number }\end{array}$ & $\begin{array}{c}\text { USGS site } \\
\text { identification } \\
\text { number }\end{array}$ & $\begin{array}{c}\text { California state well } \\
\text { number }\end{array}$ & $\begin{array}{c}\text { Date sampled } \\
\text { (mm/dd/yyy) }\end{array}$ & $\begin{array}{c}\text { Number } \\
\text { of total } \\
\text { coliforms } \\
\text { (CFUs) }\end{array}$ & $\begin{array}{c}\text { Number of } \\
\text { non-target } \\
\text { colonies } \\
\text { (CFUs) }\end{array}$ \\
\hline K47 & S3-MACK-K47 & 364600119240001 & 013S024E30L002M & $03 / 03 / 2014$ & 98 & 46 \\
K48 & S3-MACK-K48 & 365000119320001 & 012S022E35N001M & $02 / 24 / 2014$ & 0 & 1 \\
K49 & S3-MACK-K49 & 365200119330001 & 012S022E22P001M & $02 / 26 / 2014$ & 6 & 2 \\
M01 & S3-MACK-M01 & 364600120110001 & 013S016E25D003M & $03 / 19 / 2014$ & 38 & 68 \\
M02 & S3-MACK-M02 & 365400120160001 & 012S015E12A001M & $04 / 08 / 2014$ & 0 & 2 \\
M03 & S3-MACK-M03 & 365600120180001 & 011S015E27H001M & $04 / 10 / 2014$ & 9 & 29 \\
M04 & S3-MACK-M04 & 365700120220001 & 011S015E19Q001M & $04 / 10 / 2014$ & 1 & 3 \\
M12 & S3-MACK-M12 & 364900120030001 & 013S017E01J001M & $03 / 18 / 2014$ & 0 & 0 \\
M17 & S3-MACK-M17 & 370700120210001 & 009S015E29K001M & $03 / 20 / 2014$ & 0 & 0 \\
M25 & S3-MACK-M25 & 365800119530001 & 011S019E15L001M & $03 / 19 / 2014$ & 0 & 0 \\
M28 & S3-MACK-M28 & 370700120040001 & 009S017E26A001M & $04 / 09 / 2014$ & 1 & 1 \\
\hline
\end{tabular}

Table 2. Genera of bacteria that were identified as target and non-target colonies on MI media where DNA was successfully sequenced from 14 groundwater samples collected from 13 domestic wells in the southeastern San Joaquin Valley from January to April 2014.

[DNA sequences identified more than one potential genera for five of the colonies. Query coverage is the percentage of the sequence length of the colony DNA that is aligned with DNA segments of the BLAST database sequence. Identity is the extent to which the two sequences have the same nucleotide at the same position in an alignment. R, laboratory replicate]

\begin{tabular}{lllcc}
\hline $\begin{array}{c}\text { Well } \\
\text { identification } \\
\text { number }\end{array}$ & $\begin{array}{c}\text { Sequence } \\
\text { file name }\end{array}$ & Genera name & $\begin{array}{c}\text { Query } \\
\text { coverage } \\
\text { (percent) }\end{array}$ & $\begin{array}{c}\text { Identity } \\
\text { (percent) }\end{array}$ \\
\hline \multicolumn{4}{c}{ Genera identified from target colonies } \\
\hline K28 & Batch 2-03 & Pantoea & 100 & 99 \\
K30 & Batch 1-05_R & Pseudomonas or & 95 & 99 \\
& & Thalassospira & 100 & 99 \\
K30 & Batch 1-07 & Pseudomonas or & 95 & 99 \\
& & Thalassospira & 100 & 99 \\
K30 & Batch 1-06 & Erwinia & 100 & 99 \\
K31 & Batch 1-09 & Agrobacterium & 100 & 99 \\
K45 & Batch 1-11 & Chryseobacterium & 98 & 87 \\
K45 & Batch 1 -12 & Pseudomonas & 100 & 99 \\
K46 & Batch 1-23 & Chryseobacterium & 99 & 95 \\
K46 & Batch 1-20 & Achromobacter & 100 & 97 \\
K46 & Batch 1-25 & Achromobacter & 100 & 97 \\
K46 & Batch 1 -28 & Cupriavidus & 100 & 97
\end{tabular}


Table 2. Genera of bacteria that were identified as target and non-target colonies on MI media where DNA was successfully sequenced from 14 groundwater samples collected from 13 domestic wells in the southeastern San Joaquin Valley from January to April 2014.

\section{-Continued}

[DNA sequences identified more than one potential genera for five of the colonies. Query coverage is the percentage of the sequence length of the colony DNA that is aligned with DNA segments of the BLAST database sequence. Identity is the extent to which the two sequences have the same nucleotide at the same position in an alignment. R, laboratory replicate]

\begin{tabular}{|c|c|c|c|c|}
\hline $\begin{array}{c}\text { Well } \\
\text { identification } \\
\text { number }\end{array}$ & $\begin{array}{l}\text { Sequence } \\
\text { file name1 }\end{array}$ & Genera name & $\begin{array}{c}\text { Query } \\
\text { coverage } \\
\text { (percent) }\end{array}$ & $\begin{array}{c}\text { Identity } \\
\text { (percent) }\end{array}$ \\
\hline \multicolumn{5}{|c|}{ Genera identified from target colonies - Continued } \\
\hline \multirow[t]{2}{*}{ K49 } & Batch 1-37 & Tyzzerella or & 99 & 96 \\
\hline & & Streptomyces & 99 & 96 \\
\hline M01 & Batch 2-05 & Pseudomonas & 100 & 99 \\
\hline M01 & Batch 2-06 & Pseudomonas & 100 & 98 \\
\hline M03 & Batch 3-08_R & Acinetobacter & 100 & 99 \\
\hline M03 & Batch 3-09 & Acinetobacter & 100 & 88 \\
\hline M03 & Batch 3-10 & Ochrobactrum & 100 & 98 \\
\hline M03 & Batch 3-11 & Sphingobacterium & 79 & 99 \\
\hline M04 & Batch 3-13 & Cupriavidus & 100 & 98 \\
\hline \multicolumn{5}{|c|}{ Genera identified from non-target colonies } \\
\hline K09 & Batch 1-01 & Chryseobacterium & 99 & 92 \\
\hline K09 & Batch 1-02 & Chryseobacterium & 100 & 98 \\
\hline K42 & Batch 2-01 & Achromobacter & 100 & 99 \\
\hline K42 & Batch 2-02 & Achromobacter & 100 & 99 \\
\hline K44 & Batch 1-10 & Chryseobacterium & 100 & 100 \\
\hline K46 & Batch 1-14 & Curtobacterium & 100 & 99 \\
\hline K46 & Batch 1-16 & Rhodococcus & 100 & 97 \\
\hline K46 & Batch 1-29 & Pseudomonas & 100 & 99 \\
\hline K48 & Batch 1-33 & Sphingobium & 100 & 95 \\
\hline \multirow[t]{2}{*}{ M01 } & Batch 2-07 & Pseudomonas or & 96 & 98 \\
\hline & & Thalassospira & 100 & 99 \\
\hline M02 & Batch 3-03 & Cupriavidus & 100 & 99 \\
\hline M02 & Batch 3-04 & Stenotrophomonas & 100 & 98 \\
\hline M03 & Batch 3-07 & Brevibacterium & 83 & 99 \\
\hline \multirow[t]{2}{*}{ M04 } & Batch 3-12 & Pseudomonas or & 95 & 99 \\
\hline & & Thalassospira & 100 & 99 \\
\hline M04 & Batch 3-14 & Mycolicibacterium & 100 & 100 \\
\hline
\end{tabular}

${ }^{1}$ Sequence files can be found in Soldavini and others, 2021. 
Table 3. Pathogenicity, microbial source, and selected references for genera identified in samples collected from wells in the southeastern San Joaquin Valley from January to April 2014.

[Pathogenicity may vary from species to species within a specified genus. Abbreviation: PAH, polycyclic aromatic hydrocarbons]

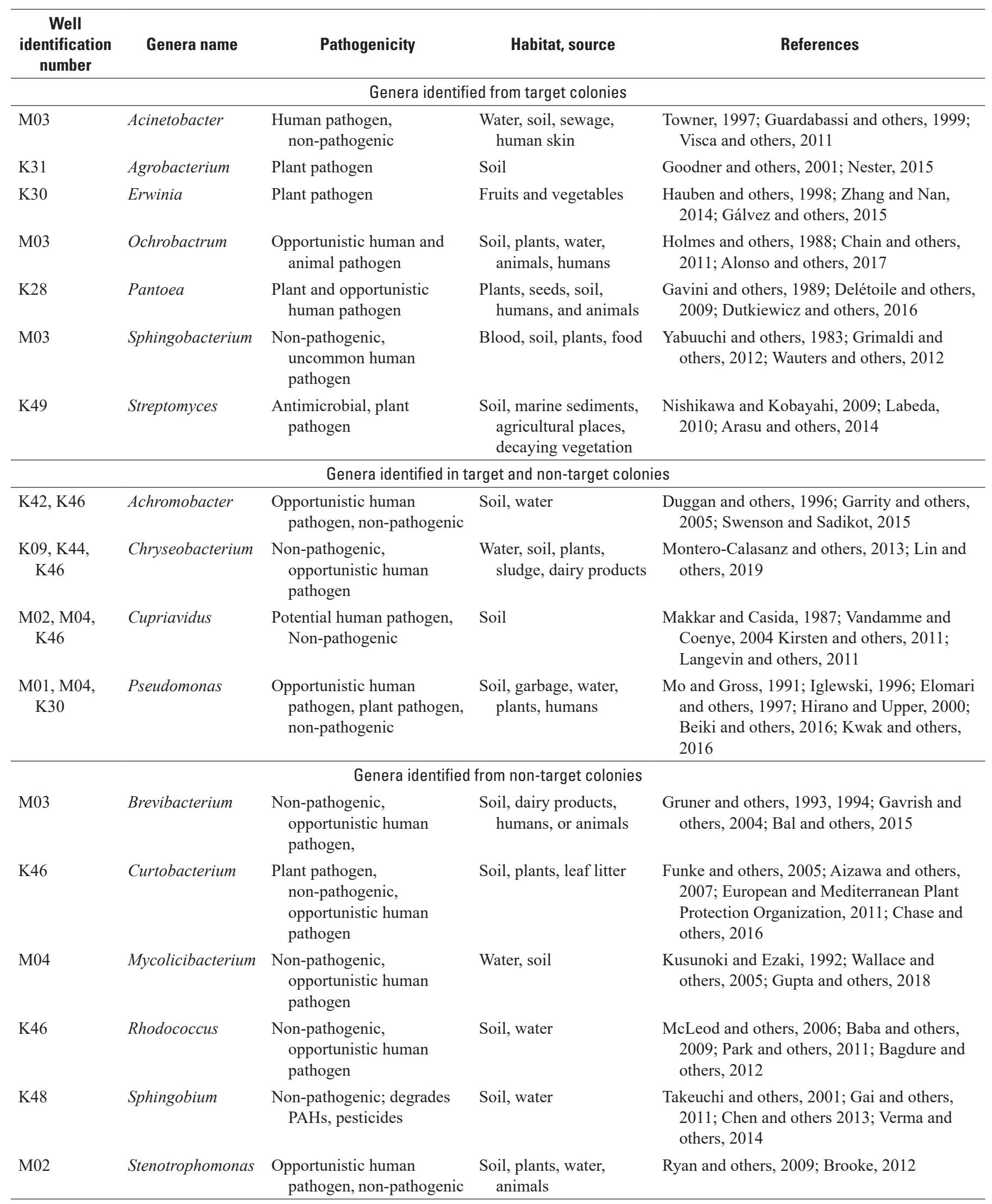


Table 3. Pathogenicity, microbial source, and selected references for genera identified in samples collected from wells in the southeastern San Joaquin Valley from January to April 2014. —Continued

[Pathogenicity may vary from species to species within a specified genus. Abbreviation: PAH, polycyclic aromatic hydrocarbons]

\begin{tabular}{|c|c|c|c|c|}
\hline $\begin{array}{c}\text { Well } \\
\text { identification } \\
\text { number }\end{array}$ & Genera name & Pathogenicity & Habitat, source & References \\
\hline \multicolumn{5}{|c|}{ Other genera identified from gene sequences but not likely to be present } \\
\hline M01, K30 & Thalassospira & $\begin{array}{l}\text { Possible therapeutic } \\
\text { applications }\end{array}$ & Marine water, plants & $\begin{array}{l}\text { López-López and others, 2002; Liu and } \\
\text { others, 2007; Tsubouchi and others, } 2014\end{array}$ \\
\hline K49 & Tyzzerella & Potential pathogen & Fecal & $\begin{array}{l}\text { Yutin and Galperin, 2013; Ascher and } \\
\text { Reinhardt, 2018; Fomenky and others, } \\
2018\end{array}$ \\
\hline
\end{tabular}

\section{Discussion}

\section{Bacteria Identification}

Culture media are designed to promote growth of desired bacteria while minimizing growth of non-target bacteria. The MI media contains an antibiotic to supress the growth of non-target bacteria; however, the antibiotic does not prevent the growth of all non-target bacteria. For example, non-target colonies can grow when there is an unusually high population of bacteria in the sample (Brenner and others, 1993; Alonso and others, 1996), and the results from this study are consistent with that behavior. The median number of total colonies in samples having eight or more non-target colonies is significantly greater than the median number of total colonies in samples having five or fewer non-target colonies (Wilcoxon rank-sum test, $\mathrm{p}<0.001$; data in table 2 ). Growth of non-target colonies also could indicate that the antibiotic in the MI media was becoming ineffective. However, Control cultures grown on each lot of MI media used indicated the antibiotic was functioning properly. Whether the bacterium is a target colony or non-target colony is less important than whether the bacterium is an indicator that pathogenic bacteria may be present in the groundwater.

The MI test is known to be less than 100 percent accurate. Maheux and others (2008) found a false-negative rate of 26 percent and a false-positive rate of 3.4 percent for TCs. Brenner and others (1993) found a false-negative rate of 4.3 percent and a false-positive rate of 6.9 percent. Four genera of bacteria, Achromobacter, Chryseobacterium, Cupriavidus, and Pseudomonas, were identified both in target and non-target colonies from samples. Some Pseudomonas and Cupriavidus species may have positive $\beta$-D-galactosidase reactions (Mo and Gross, 1991; Kirsten and others, 2011), which could explain why these bacteria may form colonies that fluoresce blue. Some of the colonies for these four genera could have contained more than one species. An additional species could have caused blue fluorescence that was not identified by the PCR analysis.

Despite that fact that the FlashGel results indicated that amplification had been successful for samples from 59 colonies, samples from only 34 colonies were successfully sequenced by GeneWiz. The primers had not properly annealed in the samples from the other 25 colonies. Use of primers other than or in addition to the $8 \mathrm{~F}$ and $787 \mathrm{R}$ primers might have resulted in better success. Lengthening the time or a using different temperature for the annealing process in the thermocycler may also have improved the results of this process. Errors in oligonucleotide sequencing also are possible. Accumulation of polymorphisms in conservative regions of the $16 \mathrm{~S}$ gene can lead to failure in primer annealing (Hall, 1994). Widely used primers may not be suitable for a small group of bacteria. For two samples, the quality of the DNA was too poor for sequencing. The lower certainty of genera identification for some of the bacteria primarily was due to poor condition of the DNA or to high background noise, which limited the contiguous read length of base pairs. For most of the genera with identity at less than 99 percent certainty, poor condition of the sequence sample resulted in sequences with fewer bases. Potential bias in the success of colony sequencing could not be evaluated because the success rate was about one-third both for target colonies and non-target colonies. 
Uncertainties in the identification of a bacteria can result from similarities in the gene sequence in the area amplified by the universal primers. This study had two samples for which the possible genera were not closely related but had similar gene sequences in the area amplified. Pseudomonas and Thalassospira were possible candidate genera for two colonies from the K30 sample and one colony from the M01 sample. Pseudomonas had lower query coverages than Thalassospira, although the certainty of identity percentages was similar (table 2). A search of the literature for the two genera, however, showed that Thalassospira is found in saline waters because it is strictly halophilic (López-López and others, 2002; Liu and others, 2007; Tsubouchi and others, 2014), indicating that Pseudomonas is the more likely genus of the two potential candidates. Tyzzerella and Streptomyces were possible candidate genera for a target colony from the K49 sample. Tyzzerella are anaerobic bacteria that are present in fecal matter and are often found in human intestinal systems (Holdeman and Moore, 1974; Ascher and Reinhardt, 2018; Fomenky and others, 2018), and Streptomyces are aerobic, filamentous, bacteria present in soil (Arasu and others, 2014). The K49 water sample was highly oxygenated (Shelton and Fram, 2017), which indicates that the aerobic bacterium Streptomyces is the more likely candidate of the two genera.

\section{Pathogenicity of Identified Bacteria}

A review of relevant literature revealed that one genus identified included at least one species that was a human pathogen and 12 more genera included species that could be opportunistic or potential human pathogens (table 3). Most of the potential pathogenic bacteria were not coliforms, however, based on the MI description of a coliform used in this report. Only three coliform genera were target bacteria that could be opportunistic human pathogens. The other coliform genera were either non-pathogenic or were plant pathogens. One coliform genus, Pantoea, includes species that are both a plant pathogen and an opportunistic human pathogen. This study confirms that the detection of TCs does not always indicate the presence of potentially pathogenic bacteria, nor does the non-detection of TCs always indicate the absence of potentially pathogenic bacteria (table 3 ). The results support the hypothesis that the MI test may be useful in determining if groundwater is contaminated with pathogenic bacteria.

Some non-target bacteria genera identified were pathogenic as well. Nine non-target genera included species that could be human pathogens or opportunistic human pathogens (including the four genera that manifested as both target and non-target colonies). This indicates the MI test is useful in determining the possibility of water contaminated with pathogenic bacteria even if the bacteria are not target bacteria.

One non-target genus, Sphingobium, was non-pathogenic. Interestingly, Sphingobium is known to degrade polycyclic aromatic hydrocarbons (PAHs) as well as pesticides (Gai and others, 2011); therefore, the presence of Sphingobium might help reduce concentrations of contaminants in the aquifer. It could, however, also indicate point or non-point source pollution of pesticides or PAHs upgradient from the well. One target genus that is a plant pathogen, Streptomyces, also has antimicrobial characteristics that may be beneficial to humans (Nishikawa and Kobayahi, 2009; Arasu and others, 2014).

Some genera consist of non-pathogenic and potentially human pathogenic species. In this study, the species present in the water samples could not be definitively identified to determine pathogenicity. Given the number of genera identified with potentially pathogenic species, the results indicate that pathogenic bacteria could be widely distributed throughout the study area. The FIBs detected in wells can be removed by disinfecting the well or treating water used for consumption.

\section{Potential Sources of Identified Bacteria}

Coliform bacteria are used as indicator bacteria because they live in the intestines of warm-blooded animals and may be an indicator of possible fecal contamination; however, coliforms also can live in environments not contaminated by feces or sewage (Brennan and others, 2010). Coliforms are present in water, soil, garbage, skin, nonfecal bodily fluids, and on plants (DeSimone and others, 2009). Aerobic, Gram-negative rod bacteria are widely distributed in soils and shallow groundwater and include such genera as Pseudomonas, Flavobacterium, Rhizobium, Alcaligenes, and Azotobacter (Chapelle, 2001). Because of the many sources of bacteria, contamination of domestic wells by bacteria is common (DeSimone and others, 2009). Knowing the source or potential sources of bacteria can help well owners determine if bacterial contamination of well water is a continuous or occasional threat. Well owners can remove bacterial contamination from the well by disinfecting the well as needed or by removing the source of contamination. 
Bacteria identified in this study were present in a variety of media. Of the 17 genera, 16 were present in soil; 9 were present in water; 9 were present in or on plants, fruits or vegetables; 6 were present on humans or animals; and 4 were present in other media such as dairy products, garbage, and blood (table 3). Many bacteria were present in more than one medium. Not surprisingly, almost all the genera identified are naturally present in soil or groundwater, indicating that the primary source of the bacteria in most wells is the soil and not septic systems. Bacteria from other sources, such as blood, feces, garbage, or dairy products, could enter the groundwater system through septic systems or infiltration from the ground surface with precipitation, irrigation, or other water usage. The presence of soil bacteria in samples from wells could indicate problems with the well seal allowing surface water to flow into the well or relatively short travel times between recharge and the well (that is, no attenuation of bacteria by percolation through the aquifer). Many of the domestic wells in this study are in areas of the San Joaquin Valley dominated by vertical groundwater flow paths and coarse-grained sediments that have relatively fast recharge rates (Faunt, 2009). The wells are relatively shallow with median depth of $55 \mathrm{~m}$ below land surface, and the median depth to water is $25 \mathrm{~m}$ below land surface; thus, even in the absence of short-circuiting of flow paths through insufficient well seals, the distance the water traveled through the aquifer to the well was likely relatively short. Nearly all of the samples were primarily composed of modern-age water that was recharged into the aquifer between 1 and 70 years prior to sample collection (Faulkner and Jurgens, 2019). The combination of aquifer conditions and well characteristics favoring rapid recharge and the young age of the water tapped by the wells indicates that these wells may be susceptible to surface contamination.

All 13 genera identified in this study that could have potentially human pathogenic species can be found naturally in soils, plants, or groundwater, but animals are also potential sources for 6 of these 13 genera. The non-pathogenic and plant-pathogenic bacteria are found naturally in soils, plants, and groundwater. The presence of TCs and non-target bacteria growth on MI media indicates the possible presence of pathogens, but the pathogens may not be of fecal or even mammalian origin. The TCs and other detected pathogens could be removed by disinfecting wells or identifying and fixing issues with well seals.

\section{Conclusions}

Domestic wells are an important source of drinking water in the southeastern San Joaquin Valley, California, and microbial contamination in those wells could cause water-borne diseases. Forty-two domestic wells were sampled in 2014 in the Chowchilla, Madera, and Kings groundwater subbasins of the San Joaquin Valley for a study to identify the species of bacteria present in groundwater used by domestic wells. The study was part of the Groundwater Ambient Monitoring and Assessment Program Priority Basin Project (GAMA-PBP), a cooperative study between the U.S. Geological Survey and the California State Water Resources Control Board.

The MI test, a membrane filtration method for the chromogenic/fluorogenic detection of total coliforms and Escherichia coli, was used to test for the presence of coliform bacteria. Samples from almost two-thirds of the wells analyzed (27 of 42) had microbial growth on MI media. The microbial growth for 20 wells included target coliform colonies and included non-target colonies for 18 wells. Polymerase chain reaction analysis (PCR) and deoxyribonucleic acid (DNA) sequencing were used to identify genera of bacteria in 34 of the target and nontarget colonies from 13 wells. Gene sequences obtained using the Sanger method were entered into the basic local alignment search tool (BLAST) database, and 17 genera of bacteria were identified. Of these 17 genera, 13 genera include species that are human pathogens or opportunistic human pathogens. More than half the genera with possible human pathogenic bacteria were isolated from non-target colonies that grew on the MI medium; therefore, the presence of total coliforms is not a strong indicator of the presence of human pathogens. The MI test was useful in determining the possibility that water may be contaminated with pathogenic bacteria, however, even if the bacteria are not coliforms. A couple of the genera identified included bacteria that could be beneficial to humans. Streptomyces has antimicrobial characteristics, and Sphingobium can degrade pesticides and polycyclic aromatic hydrocarbons (PAHs).

Microbial contamination in domestic wells does not necessarily mean that the source of the contamination is fecal. Based on a literature search, all 13 of the genera that include possible human pathogens are natural inhabitants of soils, plants, or groundwater. Six of the genera also have animals and humans as one of the potential sources. All the non-pathogenic and plant pathogenic bacteria are found naturally in soils, plants, or groundwater. This indicates that the sources of bacteria to these domestic wells are most likely soil, not human fecal matter from septic systems. Disinfecting the well or fixing leaky well seals can help remove bacterial growth identified from analyzed samples of well water. Future studies could investigate the relation of microbial communities with water quality and other environmental factors. 


\section{References Cited}

Aizawa, T., Ve, N.B., Kimoto, K., Iwabuchi, N., Sumida, H., Hasegawa, I., Sasaki, S., Tamura, T., Kudo, T., Suzuki, K., Nakajima, M., and Sunairi, M., 2007, Curtobacterium ammonniigenes sp. nov., an ammonia-producing bacterium isolated from plants inhabiting acidic swamps in actual acid sulfate soil areas of Vietnam: International Journal of Systematic and Evolutionary Microbiology, v. 57, no. 7, p. 1447-1452, https://doi.org/10.1099/ijs.0.64731-0.

Alonso, J.L., Amoros, I., and Alonso, M.A., 1996, Differential susceptibility of aeromonads and coliforms to cefsulodin: Applied and Environmental Microbiology, v. 62, no. 6, p. 1885-1888, https://doi.org/10.1128/AEM.62.6.1885-1888.1996.

Alonso, C.A., Kwabugge, Y.A., Anyanwu, M.U., Torres, C., and Chah, K.F., 2017, Diversity of Ochrobactrum species in food animals, antibiotic resistance phenotypes and polymorphisms in the bla $\mathrm{OCH}$ gen: FEMS Microbiology Letters, v. 364, no. 17, 7 p., https://doi.org/10.1093/femsle/fnx178.

Arasu, M.V., Rejiniemon, T.S., Huxley, V.A.J., Ilavenil, S., Duraipandiyan, V., Al-Dahabi, N.A., Kim, D.H., Lee, K.D., and Choi, K., 2014, Identification of poly ketide gene from Streptomyces roseoverticillatus and its antimicrobial properties against pathogenic bacteria and fungi: Journal of Pure \& Applied Microbiology, v. 8, p. 59-67.

Ascher, S., and Reinhardt, C., 2018, The gut microbiota-An emerging risk factor for cardiovascular and cerebrovascular disease: European Journal of Immunology, v. 48, no. 4, p. 564-575, https://doi.org/10.1002/eji.201646879.

Baba, H., Nada, T., Ohkusu, K., Ezaki, T., Hasegawa, Y., and Paterson, D.L., 2009, First case of bloodstream infection caused by Rhodococcus erythropolis: Journal of Clinical Microbiology, v. 47, no. 8, p. 2667-2669, https://doi.org/10.1128/jcm.00294-09.

Bagdure, S.R., Fisher, M.A., Ryan, M.E., and Khasawneh, F.A., 2012, Rhodococcus erythropolis encephalitis in patient receiving rituximab: Emerging Infectious Diseases, v. 18, no. 8, p. 1378-1379, https://doi.org/10.3201/eid1808.110434.

Bal, Z.S., Sen, S., Karapinar, D.Y., Aydemir, S., and Vardar, F., 2015, The first reported catheter-related Brevibacterium casei bloodstream infection in a child with acute leukemia and review of the literature: The Brazilian Journal of Infectious Diseases, v. 19, no. 2, p. 213-215, https://doi.org/10.1016/j.bjid.2014.09.011.
Barry, T., Colleran, G., Glennon, M., Dunican, L.K., and Gannon, F., 1991, The 16S/23s ribosomal spacer region as a target for DNA probes to identify eubacteria: PCR Methods and Applications, v. 1, no. 1, p. 51-56, https://doi.org/10.1101/gr.1.1.51.

Beiki, F., Busquets, A., Gomila, M., Rahimian, H., Lalucat, J., and García-Valdés, E., 2016, New Pseudomonas spp. are pathogenic to citrus: PLoS One, v. 11, no. 2, 16 p., https://doi.org/10.1371/journal.pone.0148796.

Benedict, K.M., Reses, H., Vigar, M., Roth, D.M., Roberts, V.A., Mattioli, M., Cooley, L.A., Hilborn, E.D., Wade, T.J., Fullerton, K.E., Yoder, J.S., and Hill, V.R., 2017, Surveillance for waterborne disease outbreaks associated with drinking water-United States, 2013-2014: Morbidity and Mortality Weekly Report, Centers for Disease Control and Prevention, v. 66, no. 44, p. 1216-1221, https://doi.org/10.15585/mmwr.mm6644a3.

Brennan, F.P., Abram, F., Chinalia, F.A., Richards, K.G., and O'Flaherty, V., 2010, Characterization of environmentally persistent Escherichia coli isolates leached from an Irish soil: Applied and Environmental Microbiology, v. 76, no. 7, p. 2175-2180, https://doi.org/10.1128/AEM.01944-09.

Brenner, K.P., Rankin, C.C., Roybal, Y.R., Stelma, G.N., Jr., Scarpino, P.V., and Dufour, A.P., 1993, New medium for the simultaneous detection of total coliforms and Escherichia coli in water: Applied and Environmental Microbiology, v. 59, no. 11, p. 3534-3544, https://doi.org/10.1128/aem.59.11.3534-3544.1993.

Brenner, K.P., Rankin, C.C., and Sivaganesan, M., 1996, Interlaboratory evaluation of MI agar and the US Environmental Protection Agency-approved membrane filter method for the recovery of total coliforms and Escherichia coli from drinking water: Journal of Microbiological Methods, v. 27, no. 2-3, p. 111-119, https://doi.org/10.1016/S0167-7012(96)00932-3.

Brooke, J.S., 2012, Stenotrophomonas maltophiliaAn emerging global opportunistic pathogen: Clinical Microbiology Reviews, v. 25, no. 1, p. 2-41, https://doi.org/10.1128/cmr.00019-11.

Buckalew, D.W., Hartman, L.J., Grimsley, G.A., Martin, A.E., and Register, K.M., 2006, A long-term study comparing membrane filtration with colilert defined substrates in detecting fecal coliforms and Escherichia coli in natural waters: Journal of Environmental Management, v. 80, no. 3, p. 191-197, https://doi.org/10.1016/j.jenvman.2005.08.024.

California State Water Resources Control Board, 2015, A guide for private domestic well owners: California State Water Resources Control Board, Groundwater Ambient Monitoring and Assessment Program, 22 p., accesses May 11, 2021, at https://www.waterboards.ca.gov/gama/ docs/wellowner_guide.pdf. 
California State Water Resources Control Board, 2018, GAMA - Domestic well project site: California State Water Resources Control Board, Groundwater Ambient Monitoring and Assessment Program website, accessed May 11, 2021, at https://www.waterboards.ca.gov/water issues/programs/gama/domestic_well.html.

California State Water Resources Control Board, 2019, California Code of Regulations-Title 22, Division 4 Environmental Health, Chapter 15 Domestic water quality and monitoring regulations: California State Water Resources Control Board, Division of Drinking Water, accessed October 15, 2019, at https://www.waterboards.ca.gov/drinking_water/certlic/ drinkingwater/Lawbook.html.

California Department of Water Resources, 2003, California's groundwater update 2003: California Department of Water Resources Bulletin 118, accessed January 28, 2015, at https:/cawaterlibrary.net/document/bulletin-118-californiasgroundwater-2003/.

California Department of Water Resources, 2008a, California's groundwater-Individual basin descriptionsSan Joaquin River hydrologic region, San Joaquin Valley groundwater basin, Chowchilla subbasin: California Department of Water Resources Bulletin 118, accessed January 28, 2015, at https://water.ca.gov/-/media/DWRWebsite/Web-Pages/Programs/Groundwater-Management/ Bulletin-118/Files/2003-Basin-Descriptions/5_022_05_Ch owchillaSubbasin.pdf.

California Department of Water Resources, 2008b, California's groundwater-individual basin descriptionsSan Joaquin River hydrologic region, San Joaquin Valley groundwater basin, Madera subbasin: California Department of Water Resources Bulletin 118, accessed January 28, 2015, at https://water.ca.gov/-/media/DWRWebsite/Web-Pages/Programs/Groundwater-Management/ Bulletin-118/Files/2003-Basin-Descriptions/5_022_06_ MaderaSubbasin.pdf.

Chain, P.S.G., Lang, D.M., Comerci, D.J., Malfatti, S.A., Vergez, L.M., Shin, M., Ugalde, R.A., Garcia, E., and Tolmasky, M.E., 2011, Genome of Ochrobactrum anthropi ATCC $49288^{\mathrm{T}}$, a versatile opportunistic pathogen and symbiont of several eukaryotic hosts: Journal of Bacteriology, v. 193, no. 16, p. 4272-4275, https://doi.org/10.1128/JB.05335-11.

Chapelle, F.H., 2001, Ground-water microbiology and geochemistry: New York, John Wiley \& Sons, 477 p.

Chase, A.B., Arevalo, P., Polz, M.F., Berlemon, T.R., and Martiny, J.B.H., 2016, Evidence for ecological flexibility in the cosmopolitan genus Curtobacterium: Frontiers in Microbiology, v. 7, no. 7, 11 p., https://doi.org/10.3389/fmicb.2016.01874.
Chen, H., Jogler, M., Rohde, M., Klenk, H.-P., Busse, H.-J., Tindall, B.J., Spröer, C., and Overmann, J., 2013, Sphingobium limneticum sp. nov. and Sphingobium boeckii sp. nov., two freshwater planktonic members of the family Sphingomonadaceae, and reclassification of Sphingomonas suberifaciens as Sphingobium suberifaciens comb. nov: International Journal of Systematic and Evolutionary Microbiology, v. 63, pt. 2, p. 735-743, https://doi.org/10.1099/ijs.0.040105-0.

Clermont, O., Bonacorsi, S., and Bingen, E., 2000, Rapid and simple determination of the Escherichia coli phylogenetic group: Applied and Environmental Microbiology, v. 66, no. 10, p. 4555-4558, https://doi.org/10.1128/AEM.66.10.4555-4558.2000.

Covert, T.C., Shadix, L.C., Rice, E.W., Haines, J.R., and Freyberg, R.W., 1989, Evaluation of the autoanalysis colilert test for detection and enumeration of total coliforms: Applied and Environmental Microbiology, v. 55, no. 10, p. 2443-2447, https://doi.org/10.1128/AEM.55.10.2443-2447.1989.

Davis, G.H., Green, J.H., Olmsted, F.H., and Brown, D.W., 1959, Ground-water conditions and storage capacity in the San Joaquin Valley, California: U.S. Geological Survey Water Supply Paper 1469, 287 p., https://pubs.er.usgs.gov/publication/wsp1469.

Delétoile, A., Decré, D., Courant, S., Passet, V., Audo, J., Grimont, P., Arlet, G., and Brisse, S., 2009, Phylogeny and identification of Pantoea species and typing of Pantoea agglomerans strains by multilocus gene sequencing: Journal of Clinical Microbiology, v. 47, no. 2, p. 300-310, https://doi.org/10.1128/JCM.01916-08.

DeSimone, L.A., Hamilton, P.A., and Gilliom, R.J., 2009, Quality of water from domestic wells in principal aquifers of the United States, 1991-2004-Overview of major findings: U.S. Geological Survey Circular 1332, 48 p., https://doi.org/10.3133/cir1332

Dieter, C.A., Maupin, M.A., Caldwell, R.R., Harris, M.A., Ivahnenko, T.I., Lovelace, J.K., Barber, N.L., and Linsey, K.S., 2018, Estimated use of water in the United States in 2015: U.S. Geological Survey Circular 1441, 65 p., https://doi.org/10.3133/cir1441.

Duggan, J.M., Goldstein, S.J., Chenoweth, C.E., Kauffman, C.A., and Bradley, S.F., 1996, Achromobacter xylosoxidans bacteremia-Report of four cases and review of the literature: Clinical Infectious Diseases, v. 23, no. 3, p. 569-576, https://doi.org/10.1093/clinids/23.3.569. 
Dutkiewicz, J., Dutkiewicz, B., Lemieszek, M.K., Golec, M., and Milanowski, J., 2016, Pantoea agglomerans - A mysterious bacterium of evil and good. Part III. Deleterious effects-Infections of humans, animals and plants: Annals of Agricultural and Environmental Medicine, v. 23, no. 2, p. 197-205, https://doi.org/10.5604/12321966.1203878.

Elomari, M., Coroler, L., Verhille, S., Izard, D., and Leclerc, H., 1997, Pseudomonas monteilii sp. nov., isolated from clinical specimens: International Journal of Systematic Bacteriology, v. 47, no. 3, p. 846-852, https://doi.org/10.1099/00207713-47-3-846.

Fassler, J., and Cooper, P., 2011, BLAST glossary, in National Center for Biotechnology Information, BLAST help_-NCIB help manual: Bethesda MD, National Center for Biotechnology Information (US), https://www.ncbi.nlm.nih.gov/books/NBK62051/.

Faulkner, K.E., and Jurgens, B.C., 2019, Data for assessing the susceptibility of groundwater used for drinking water supply from selected principal aquifers of the Western United States, 2004-2018: U.S. Geological Survey data release, https://doi.org/10.5066/P9U9ZSBN.

Faunt, C.C., ed., 2009, Groundwater availability of the Central Valley Aquifer, California, U.S. Geological Survey Professional Paper 1766, 227 p., https://doi.org/10.3133/pp1766.

Fomenky, B.E., Do, D.N., Talbot, G., Chiquette, J., Bissonnette, N., Chouinard, Y.P., Lessar, M., and Ibeaghu-Awemu, E.M., 2018, Direct-fed microbial supplementation influences the bacteria community composition of the gastrointestinal tract of pre- and post-weaned calves: Scientific Reports, v. 8, no. 1, 21 p., https://doi.org/10.1038/s41598-018-32375-5.

Foppen, J.W.A., and Schijven, F., 2006, Evaluation of data from the literature on the transport and survival of Escherichia coli and thermotolerant coliforms in aquifers under saturated conditions: Water Resources, v. 40, no. 3, p. 401-426, https://doi.org/10.1016/j.watres.2005.11.018.

Funke, G., Aravena-Roman, M., and Frodl, R., 2005, First description of Curtobacterium spp. isolated from human clinical specimens: Journal of Clinical Microbiology, v. 43, no. 3, p. 1032-1036, https://doi.org/10.1128/JCM.43.3.1032-1036.2005.

Gai, Z., Wang, X., Tang, H., Tai, C., Tao, F., Wu, G., and $\mathrm{Xu}, \mathrm{P} ., 2011$, Genome sequence of Sphingobium yanoikuyae XLDN2-5, an efficient carbazole-degrading strain: Journal of Bacteriology, v. 193, no. 22, p. 6404-6405, https://doi.org/10.1128/JB.06050-11.
Gálvez, L., Gil-Serna, J., García-Díaz, M., and Palmero, D., 2015, First report of a garlic bulb rot caused by Erwinia persicina in Europe: Plant Disease, v. 99, no. 5, p. 723-724, https://doi.org/10.1094/PDIS-11-14-1195-PDN.

Garrity, G.M., Brenner, D.J., Krieg, N.R., and Staley, J.T., eds., 2005, Bergey's manual of systematic bacteriologyVolume two - The proteobacteria, part C-The Alpha-, Beta-, Delta-, and Epsilonproteobacteria: New York, Springer, 1256 p., https://doi.org/10.1007/0-387-29298-5.

Gavini, F., Mergaert, J., Beji, A., Mielcarek, C., Izard, D., Kersters, K., and De Ley, J., 1989, Transfer of Enterobacter agglomerans (Beijerinck 1888) Ewing and Fif 1972 to Pantoea gen. nov. as Panoea agglomerans comb. nov. and description of Pantoea dispersa sp. nov: International Journal of Systematic Bacteriology, v. 39, no. 3, p. 337-345, https://doi.org/10.1099/00207713-39-3-337.

Gavrish, E.Y., Krauzova, V.I., Potekhina, N.V., Karasev, S.G., Plotnikova, E.G., Altyntseva, O.V., Korosteleva, L.A., and Evtushenko, L.I., 2004, Three new species of Brevibacteria, Brevibacterium antiquum sp. nov., Brevibacterium aurantiacum sp. nov., and Brevibacterium permense sp. nov: Microbiology, v. 73, no. 2, p. 176-183, https://doi.org/10.1023/B:MICI.0000023986.52066.1e.

Goodner, B., Hinkle, G., Gattung, S., Miller, N., Blanchard, M., Qurollo, B., Goldman, B.S., Cao, Y., Askenazi, M., Halling, C., Mullin, L., Houmiel, K., Gordon, J., Vaudin, M., Iartchouk, O., Epp, A., Liu, F., Wollam, C., Allinger, M., Doughty, D., Scott, C., Lappas, C., Markelz, B., Flanagan, C., Crowell, C., Gurson, J., Lomo, C., Sear, C., Strub, G., Cielo, C., and Slater, S., 2001, Genome sequence of the plant pathogen and biotechnology agent Agrobacterium tumefaciens C58: Science, v. 294, no. 5550, p. 2323-2328, https://doi.org/10.1126/science.1066803.

Grimaldi, D., Doloy, A., Fichet, J., Bourgeois, E., Zuber, B., Wajsfisz, A., Mira, J.P., Poyart, C., and Pène, F., 2012, Necrotizing fasciitis and septic shock related to the uncommon Gram-negative pathogen Sphingobacterium multivorum: Journal of Clinical Microbiology, v. 50, no. 1, p. 202-203, https://doi.org/10.1128/JCM.05151-11.

Gruner, E., Pfyffer, G.E., and von Gravenitz, A.W.C., 1993, Characterization of Brevibacterium spp. from clinical specimens: Journal of Clinical Microbiology, v. 31, no. 6, p. 1408-1412, https://doi.org/10.1128/JCM.31.6.1408-1412.1993.

Gruner, E., Steigerwalt, A.G., Hollis, D.G., Weyant, R.S., Weaver, R.E., Moss, C.W., Daneshvar, M., Brown, J.M., and Brenner, D.J., 1994, Human infections caused by Brevibacterium casei, formerly CDC groups B-1 and B-3: Journal of Clinical Microbiology, v. 32, no. 6, p. 1511-1518, https://doi.org/10.1128/jcm.32.6.1511-1518.1994. 
Guardabassi, L., Dalsgaard, A., and Olsen, J.E., 1999, Phenotypic characterization and antibiotic resistance of Acinetobacter spp. isolated from aquatic sources: Journal of Applied Microbiology, v. 87, no. 5, p. 659-667, https://doi.org/10.1046/j.1365-2672.1999.00905.x.

Gupta, R.S., Lo, B., and Son, J., 2018, Phylogenomics and comparative genomic studies robustly support division of the genus Mycobacterium into an emended genus Mycobacterium and four novel genera: Frontiers in Microbiology, v. 9, no. 67, 41 p., https://doi.org/10.3389/fmicb.2018.00067.

Gürtler, V., and Stanisich, V.A., 1996, New approaches to typing and identification of bacteria using the $16 \mathrm{~S}-23 \mathrm{~S}$ rDNA spacer region: Microbiology, v. 142, no. 1, p. 3-16, https://doi.org/10.1099/13500872-142-1-3.

Hall, L.C., 1994, Are point mutations or DNA rearrangements responsible for the restriction fragment length polymorphisms that are used to type bacteria?: Microbiology, v. 140, p. 197-204, https://doi.org/10.1099/13500872-140-1-197.

Hauben, L., Moore, E.R.B., Vauterin, L., Steenackers, M., Mergaert, J., Verdonck, L., and Swings, J., 1998, Phylogenetic position of phytopathogens within Enterobacteriaceae: Systematic and Applied Microbiology, v. 21, no. 3, p. 384-397, https://doi.org/10.1016/s0723-2020(98)80048-9.

Hirano, S.S., and Upper, C.D., 2000, Bacteria in the leaf ecosystem with emphasis on Pseudomonas syringae-A pathogen, ice nucleus, and epiphyte: Microbiology and Molecular Biology Reviews, v. 64, no. 3, p. 624-653, https://doi.org/10.1128/mmbr.64.3.624-653.2000.

Holdeman, L.V., and Moore, W.E.C., 1974, New genus Coprococcus, twelve new species, and emended descriptions of four previously described species of bacteria from human feces: International Journal of Systematic Bacteriology, v. 24, no. 2, p. 260-277, https://doi.org/10.1099/00207713-24-2-260.

Holmes, B., Popoff, M., Kiredjian, M., and Kersters, K., 1988, Ochrobactrum anthropic gen. nov., sp. nov. from human clinical specimens and previously known as group $\mathrm{Vd}$ : International Journal of Systematic Bacteriology, v. 38, no. 4, p. 406-416, https://doi.org/10.1099/00207713-38-4-406.

Iglewski, B.H., 1996, Pseudomonas, chap. 27 of Baron, S., ed., Medical microbiology (4th ed.): Galveston, University of Texas Medical Branch at Galveston, https:/www.ncbi.nlm.nih.gov/books/NBK8326/.
Jensen, M.A., Webster, J.A., and Straus, N., 1993, Rapid identification of bacteria on the basis of polymerase chain reaction-amplified ribosomal DNA spacer polymorphisms: Applied and Environmental Microbiology, v. 59, no. 4, p. 945-952, https://doi.org/10.1128/aem.59.4.945-952.1993.

Johnson, T.D., and Belitz, K., 2015, Identifying the location and population served by domestic wells in California: Journal of Hydrology. Regional Studies, v. 3, p. 31-86, https://doi.org/10.1016/j.ejrh.2014.09.002.

Kirsten, A., Herzberg, M., Voigt, A., Seravalli, J., Grass, G., Scherer, J., and Nies, D.H., 2011, Contributions of five secondary metal uptake systems to metal homeostasis of Cupriavidus metallidurans $\mathrm{CH} 34$ : Journal of Bacteriology, v. 193, no. 18, p. 4652-4663, https://doi.org/10.1128/JB.05293-11.

Krentz, C.A., 2012, An evaluation of new and traditional approaches to monitor drinking water quality in British Columbia: Vancouver, Canada, University of British Columbia, Ph.D dissertation, 201 p., https://open.library.ubc.ca/cIRcle/collections/ubctheses/24/ items/1.0073254.

Kusunoki, S., and Ezaki, T., 1992, Proposal of Mycobacterium peregrinum sp. nov., norn. rev., and elevation of Mycobacterium chelonae subsp. abscessus (Kubica et al.) to species status-Mycobacterium abscessus comb. nov: International Journal of Systematic Bacteriology, v. 42, no. 2, p. 240-245, https://doi.org/10.1099/00207713-42-2-240.

Kwak, Y., Park, G.-S., and Shin, J.-H., 2016, High quality draft genome sequence of the type strain of Pseudomonas lutea $\mathrm{OK} 2 \mathrm{~T}$, a phosphate-solubilizing rhizospheric bacterium: Standards in Genomic Sciences, v. 11, no. 51, 10 p., https://doi.org/10.1186/s40793-016-0173-7.

Labeda, D.P., 2010, Multilocus sequence analysis of phytopathogenic species of the genus Streptomyces: International Journal of Systematic and Evolutionary Microbiology, v. 61, no. 10, p. 2525-2531, https://doi.org/10.1099/ijs.0.028514-0.

Langevin, S., Vincelette, J., Bekal, S., and Gaudreau, C., 2011, First case of invasive human infection caused by Cupriavidus metallidurans: Journal of Clinical Microbiology, v. 49, no. 2, p. 744-745, https://doi.org/10.1128/JCM.01947-10.

Levin, R.B., Epstein, P.R., Ford, T.E., Harrington, W., Olson, E., and Reichard, E.G., 2002, U.S. drinking water challenges in the twenty-first century: Environmental Health Perspectives, v. 110, no. S1, p. 43-52, https://doi.org/10.1289/ehp.02110s143. 
Lin, J.-N., Lai, C.-H., Yang, C.-H., and Huang, Y.-H., 2019, Differences in clinical manifestations, antimicrobial susceptibility patterns, and mutations of fluoroquinolone target genes between Chryseobacterium gleum and Chryseobacterium indologenes: Antimicrobial Agents and Chemotherapy, v. 63, no. 5, 10 p., https://doi.org/10.1128/AAC.02256-18.

Liu, C., Wu, Y., Li, L., Ma, Y., and Shao, Z., 2007, Thalassopira xiamenensis sp. nov. and Thalassopira profundimaris sp. nov: International Journal of Systematic and Evolutionary Microbiology, v. 57, no. 2, p. 316-320, https://doi.org/10.1099/ijs.0.64544-0.

López-López, A., Pujalte, M.J., Benlloch, S., Mata-Roig, M., Rosselló-Mora, R., Garay, E., and Rodríguez-Valera, F., 2002, Thalassospira lucentensis gen. nov., sp. nov., a new marine member of the $\alpha$-Proteobacteria: International Journal of Systematic and Evolutionary Microbiology, v. 52, p. 1277-1283, https://doi.org/10.1099/00207713-52-4-1277.

Maheux, A.F., Huppe, V., Boissinot, M., Picard, F.J., Bissonnette, L., Bernier, J.-L.T., and Bergeron, M.G., 2008, Analytical limits of four $\beta$-glucuronidase and $B$-galactosidase-based commercial culture methods used to detect Escherichia coli and total coliforms: Journal of Microbiological Methods, v. 75, no. 3, p. 506-514, https://doi.org/10.1016/j.mimet.2008.08.001.

Makkar, N.S., and Casida, L.E., Jr., 1987, Cupriavidus necator gen. nov., sp. nov.-A nonobligate bacterial predator of bacteria in soil: International Journal of Systematic Bacteriology, v. 37, no. 4, p. 323-326, https://doi.org/10.1099/00207713-37-4-323.

McLeod, M.P., Warren, R.L., Hsiao, W.W., Araki, N., Mihre, M., Fernandes, C., Miyazawa, D., Wong, W., Lillquist, A.L., Wang, D., Dosanjh, M., Hara, H., Petrescu, A., Morin, R.D., Yang, G., Stott, J.M., Schein, J.E., Shin, H., Smailus, D., Siddiqui, A.S., Marra, M.A., Jones, S.T.M., Holt, R., Brinkman, F.S.L., Miyauchi, K., Fukuda, M., Davies, J.E., Mohn, W.W., and Eltis, L.D., 2006, The complete genome of Rhodococcus sp. RHA1 provides insights into a catabolic powerhouse: Proceedings of the National Academy of Sciences of the United States of America, v. 103, no. 42, p. 15582-15587, https://doi.org/10.1073/pnas.0607048103.

Mo, Y.-Y., and Gross, D.C., 1991, Plant signal molecules activate the $\operatorname{syr} B$ gene, which is required for syringomycin production by Pseudomonas syringae pv. syringae: Journal of Bacteriology, v. 173, no. 18, p. 5784-5792, https://doi.org/10.1128/jb.173.18.5784-5792.1991.
Montero-Calasanz, M.C., Göker, M., Rohde, M., Spröer, C., Schumann, P., Busse, H.-J., Schmid, M., Tindall, B.J., Klenk, H.-P., and Camacho, M., 2013, Chryseobacterium hispalense sp. nov., a plant growth-promoting bacterium isolated from a rainwater pond in an olive plant nursery, and emended descriptions of Chryseobacterium defluvii, Chryseobacterium indologenes, Chryseobacterium wanjuense and Chryseobacterium gregarium: International Journal of Systematic and Evolutionary Microbiology, v. 63, p. 4386-4395, https://doi.org/10.1099/ijs.0.052456-0.

Myers, D.N., Stoeckel, D.M., Bushon, R.N., Francy, D.S., and Brady, A.M.G., 2014, Fecal indicator bacteria (ver. 2.1): U.S. Geological Survey Techniques of Water-Resources Investigations, book 9, chap. A7, sec. 7.1, accessed April 5, 2018, at https://pubs.water.usgs.gov/twri9A7/.

National Center for Biotechnology Information, 2019, Basic Local Alignment Search Tool (BLAST) homepage and search pages: National Center for Biotechnology Information Handout Series, 8 p., accessed multiple times, at https://ftp.ncbi.nlm.nih.gov/pub/factsheets/HowTo_ BLASTGuide.pdf.

Nester, E.W., 2015, Agrobacterium - Nature's genetic engineer: Frontiers in Plant Science, v. 5, no. 730.16 p., https://doi.org/10.3389/fpls.2014.00730.

Nishikawa, M., and Kobayahi, K., 2009, Streptomyces roseoverticillatus produces two different poly(amino acid)s-Lariat-shaped $\gamma$-poly(L-glutamic acid) and ع-poly(L-lysine): Microbiology, v. 155, no. 9, p. 2988-2993, https://doi.org/10.1099/mic.0.029694-0.

European and Mediterranean Plant Protection Organization, 2011, Curtobacterium flaccumfaciens pv. flaccumfaciens: Bulletin OEPP. EPPO Bulletin. European and Mediterranean Plant Protection Organisation, v. 41, no. 3, p. 320-328, https://doi.org/10.1111/j.1365-2338.2011.02496.x.

Oldstadt, J., Schauer, J.J., Standridge, J., and Kluender, S., 2007, A comparison of ten USEPA approved total coliform/E. coli tests: Journal of Water and Health, v. 5, no. 2, p. 267-282, https://doi.org/10.2166/wh.2007.008b.

Park, S.D., Uh, Y., Jang, I.H., Yoon, K.J., Kim, H.M., and Bae, Y.J., 2011, Rhodococcus erythropolis septicaemia in a patient with acute lymphocytic leukaemia: Journal of Medical Microbiology, v. 60, no. 2, p. 252-255, https://doi.org/10.1099/jmm.0.015412-0.

Ryan, R.P., Monchy, S., Cardinale, M., Taghavi, S., Crossman, L., Avison, M.B., Berg, G., van der Lelie, D., and Dow, J.M., 2009, The versatility and adaptation of bacteria from the genus Stenotrophomonas: Nature Reviews. Microbiology, v. 7, no. 7, p. 514-525, https://doi.org/10.1038/nrmicro2163. 
Ryu, H., Hensen, M., Elk, M., Toledo-Hernandez, C., Griffith, J., Blackwood, D., Noble, R., Gourmelon, M., Glassmeyer, S., and Domingo, J.W.S., 2013, Development of quantitative PCR assays targeting the 16S rRNA genes of Enterococcus spp. and their application to the identification of Enterococcus species in environmental samples: Applied and Environmental Microbiology, v. 79, no. 1, p. 196-204, https://doi.org/10.1128/AEM.02802-12.

Sanger, F., and Coulson, A.R., 1975, A rapid method for determining sequences in DNA by primed synthesis with DNA polymerase: Journal of Molecular Biology, v. 94, no. 3, p. 441-446, https://doi.org/10.1016/0022-2836(75)90213-2.

Sanger, F., Nicklen, S., and Coulson, A.R., 1977, DNA sequencing with chain-terminating inhibitors: Proceedings of the National Academy of Sciences of the United States of America, v. 74, no. 12, p. 5463-5467, https://doi.org/10.1073/pnas.74.12.5463.

Shelton, J.L., and Fram, M.S., 2017, Groundwater-quality data for the Madera/Chowchilla-Kings shallow aquifer study unit, 2013-14 - Results from the California GAMA Program: U.S. Geological Survey Data Series 1019, 115 p., https://doi.org/10.3133/ds1019.

Soldavini, A.L., Burton, C.A., and Lawrence, C.J., 2021, Detections of fecal indicator bacteria and DNA sequencing of selected bacterial growths in samples from the Madera/Chowchilla-Kings domestic aquifer study unit, 2014: Results from the California GAMA priority basin project: U.S. Geological Survey data release, https://doi.org/10.5066/P9X7JH11.

Swenson, C.E., and Sadikot, R.T., 2015, Achromobacter respiratory infections: Annals of the American Thoracic Society, v. 12, no. 2, p. 252-258, https://doi.org/10.1513/AnnalsATS.201406-288FR.

Takeuchi, M., Hamana, K., and Hiraishi, A., 2001, Proposal of the genus Sphingomonas sensu stricto and three new genera, Sphingobium, Novosphingobium and Sphingopyxis, on the basis of phylogenetic and chemotaxonomic analyses: International Journal of Systematic and Evolutionary Microbiology, v. 51, no. 4, p. 1405-1417, https://doi.org/10.1099/00207713-51-4-1405.

Towner, K.J., 1997, Clinical importance and antibiotic resistance of Acinetobacter spp: Journal of Medical Microbiology, v. 46, no. 9, p. 721-746, https://doi.org/10.1099/00222615-46-9-721.
Tsubouchi, T., Ohta, Y., Haga, T., Usui, K., Shimane, Y., Mori, K., and others, 2014, Thalassospira alkalitolerans sp. nov. and Thalassospira mesophila sp. nov., isolated from a decaying bamboo sunken in the marine environment, and emended description of the genus Thalassospira: International Journal of Systematic and Evolutionary Microbiology, v. 64, p. 107-115, https://doi.org/10.1099/ijs.0.056028-0.

U.S. Environmental Protection Agency, 1986, Ambient water quality criteria for bacteria: Cincinnati, Ohio, EPA-440/5-84-002, 18 p., https://www.epa.gov/sites/ production/files/2019-03/documents/ambient-wqc-bacteria1986.pdf.

U.S. Environmental Protection Agency, 2002, Method 1604 Total coliforms and Escherichia coli in water by membrane filtration using a simultaneous detection technique (MI medium): Washington, DC, EPA-821-R-02-024, 14 p., http://purl.access.gpo.gov/GPO/LPS44824.

U.S. Environmental Protection Agency, 2006, Method 1600Enterococci in water by membrane filtration using membrane-Enterococcus Indoxyl-B-D-Glucoside Agar (mEI): Washington, DC, EPA-821-R- 06-009, 36 p., https://settek.com/documents/EPA-Methods/PDF/EPAMethod-1600.pdf.

U.S. Environmental Protection Agency, 2008, Ground water rule source water monitoring methods guidance: Washington, DC, EPA/815/R-07/019, https://nepis.epa.gov/ Exe/ZyPDF.cgi?Dockey=60000M04.txt.

U.S. Environmental Protection Agency, 2020a, Private drinking water: U.S. Environmental Protction Agency Website, accessed May 11, 2021, at https://www.epa.gov/privatewells.

U.S. Environmental Protection Agency, 2020b, The Revised Total Coliform Rule (RTCR) state implementation guidance-Final: Washington, DC, EPA 816-R-20-003, https://www.epa.gov/sites/production/files/2015-10/ documents/rtcrimplementation_guidance.pdf.

U.S. Geological Survey, variously dated, The national field manual for the collection of water-quality data (version 7): U.S. Geological Survey Techniques and Method, book 9, chaps. A1-A9, https://pubs.water.usgs.gov/twri9A.

Vandamme, P., and Coenye, T., 2004, Taxonomy of the genus Cupriavidus - A tale of lost and found: International Journal of Systematic and Evolutionary Microbiology, v. 54, p. 2285-2289, https://doi.org/10.1099/ijs.0.63247-0. 
Verma, H., Kumar, R., Oldach, P., Sangwan, N., Khurana, J.P., Gilbert, J.A., and Lal, R., 2014, Comparative genomic analysis of nine Sphingobium strains: insights into their evolution and hexachlorocyclohexane $(\mathrm{HCH})$ degradation pathways: BMC Genomics, v. 15, no. 1, 19 p., https://doi.org/10.1186/1471-2164-15-1014.

Visca, P., Seifert, H., and Towner, K.J., 2011, Acinetobacter infection - an emerging threat to human health: IUBMB Life, v. 63, no. 12, p. 1048-1054, https://doi.org/10.1002/iub.534.

Wallace, R.J., Jr., Brown-Elliott, B.A., Brown, J., Steigerwalt, A.G., Hall, L., Woods, G., Cloud, J., Mann, L., Wilson, R., Crist, C., Jost, K.C., Jr., Byrer, D.E., Tang, J., Cooper, J., Stamenova, E., Campbell, B., Wolfe, J., and Turenne, C., 2005, Polyphasic characterization reveals that the human pathogen Mycobacterium peregrinum Type II belongs to the bovine pathogen species Mycobacterium senegalense: Journal of Clinical Microbiology, v. 43, no. 12, p. 5925-5935, https://doi.org/10.1128/JCM.43.12.5925-5935.2005.

Wauters, G., Janssens, M., De Baere, T., Vaneechoutte, M., and Deschaght, P., 2012, Isolates belonging to CDC group II-i belong predominately to Sphingobacterium mizutaii Yabuuchi et al. 1983-Emended descriptions of S. mizutaii and of the genus Sphingobacterium: International Journal of Systemic and Evolutionary Microbiology, v. 62, p. 2598-2601, https://doi.org/10.1099/ijs.0.037325-0.
Yabuuchi, E., Kaneko, T., Yano, I., Moss, C.W., and Miyoshi, N., 1983, Sphingobacterium gen. nov., Sphingobacterium spiritivorum comb. nov., Sphingobacterium multivorum comb. nov., Sphingobacterium mizutae sp. nov., and Flavobacterium indologenes sp. nov.-Glucose-nonfermenting gram-negative rods in CDC groups IIK-2 and IIb: International Journal of Systematic and Evolutionary Microbiology, v. 33, no. 3, p. 580-598, https://doi.org/10.1099/00207713-33-3-580.

Yutin, N., and Galperin, M.Y., 2013, A genomic update on clostridial phylogeny-Gram-negative spore formers and other misplaced clostridia: Environmental Microbiology, v. 15, no. 10, p. 2631-2641, https://doi.org/10.1111/1462-2920.12173.

Zhang, Y., Hong, P.-Y., LeChevallier, M.W., and Liu, W.-T., 2015, Phenotypic and phylogenetic identification of coliform bacteria obtained using 12 coliform methods approved by the U.S. Environmental Protection Agency: Applied and Environmental Microbiology, v. 81, p. 6012-6023, https://doi.org/10.1128/AEM.01510-15.

Zhang, Z., and Nan, Z., 2014, Erwinia persicina, a possible necrosis and wilt threat to forage or grain legumes production: European Journal of Plant Pathology, v. 139, p. 349-358, https://doi.org/10.1007/s10658-014-0390-0. 
For more information concerning the research in this report, contact the

Director, California Water Science Center

U.S. Geological Survey

6000 J Street, Placer Hall

Sacramento, California 95819

https://ca.water.usgs.gov

Publishing support provided by the U.S. Geological Survey Science Publishing Network, Sacramento Publishing Service Center 


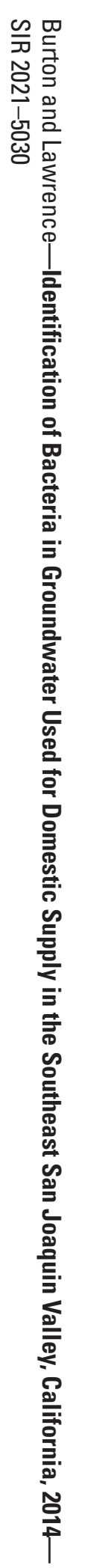

